\title{
Evolutionary history of Otophysi (Teleostei), a major clade of the modern freshwater fishes: Pangaean origin and Mesozoic radiation
}

\author{
Masanori Nakatani ${ }^{1}$, Masaki Miya ${ }^{2}$, Kohji Mabuchi $^{1}$, Kenji Saitoh $^{3}$ and Mutsumi Nishida ${ }^{1}$
}

\begin{abstract}
Background: Freshwater harbors approximately 12,000 fish species accounting for $43 \%$ of the diversity of all modern fish. A single ancestral lineage evolved into about two-thirds of this enormous biodiversity $(\approx 7900$ spp.) and is currently distributed throughout the world's continents except Antarctica. Despite such remarkable species diversity and ubiquity, the evolutionary history of this major freshwater fish clade, Otophysi, remains largely unexplored. To gain insight into the history of otophysan diversification, we constructed a timetree based on whole mitogenome sequences across 110 species representing 55 of the 64 families.

Results: Partitioned maximum likelihood analysis based on unambiguously aligned sequences (9923 bp) confidently recovered the monophyly of Otophysi and the two constituent subgroups (Cypriniformes and Characiphysi). The latter clade comprised three orders (Gymnotiformes, Characiformes, Siluriformes), and Gymnotiformes was sister to the latter two groups. One of the two suborders in Characiformes (Characoidei) was more closely related to Siluriformes than to its own suborder (Citharinoidei), rendering the characiforms paraphyletic. Although this novel relationship did not receive strong statistical support, it was supported by analyzing independent nuclear markers. A relaxed molecular clock Bayesian analysis of the divergence times and reconstruction of ancestral habitats on the timetree suggest a Pangaean origin and Mesozoic radiation of otophysans.

Conclusions: The present timetree demonstrates that survival of the ancestral lineages through the two consecutive mass extinctions on Pangaea, and subsequent radiations during the Jurassic through early Cretaceous shaped the modern familial diversity of otophysans. This evolutionary scenario is consistent with recent arguments based on biogeographic inferences and molecular divergence time estimates. No fossil otophysan, however, has been recorded before the Albian, the early Cretaceous 100-112 Ma, creating an over 100 million year time span without fossil evidence. This formidable ghost range partially reflects a genuine difference between the estimated ages of stem group origin (molecular divergence time) and crown group morphological diversification (fossil divergence time); the ghost range, however, would be filled with discoveries of older fossils that can be used as more reasonable time constraints as well as with developments of more realistic models that capture the rates of molecular sequences accurately.
\end{abstract}

\section{Background}

Although freshwater lakes and rivers occupy a small portion of the Earth's surface $(0.8 \%)$ and hold a negligible amount of the total water on Earth (0.01\%), these ecosystems support an extraordinarily high proportion of the world's biodiversity, consisting of at least 100,000 species or nearly $6 \%$ of all described species [1]. While

\footnotetext{
* Correspondence: miya@chiba-muse.or.jp

${ }^{2}$ Natural History Museum and Institute, Chiba, 955-2 Aoba-cho, Chuo-ku,

Chiba 260-8682, Japan

Full list of author information is available at the end of the article
}

this enormous biodiversity has been described through continued efforts by taxonomists, its origin and the history of the diversification on a global scale remain largely unexplored across diverse taxa. This is even true for well-studied taxa such as fishes, which account for the largest proportion of vertebrate diversity and is the taxon that controls the trophic structure of freshwater ecosystems [2].

Freshwater fishes are disproportionately species-rich. Of the currently recognized 27,977 fish species, 11,952 species (42.7\%) occur exclusively in freshwater [3]

\section{Biomed Central}


(Figure 1). These freshwater fishes are polyphyletic, being found in 30 of the 40 orders from the bottom to the top of the ray-finned fish phylogenies [3]. A single ancestral lineage, however, diversified into approximately two-thirds of this enormous diversity (7943 spp.), and it is distributed throughout the world's continents except Antarctica [4]. This clade, Series Otophysi, comprises four primarily freshwater orders (Figure 1): Cypriniformes (minnows, carps, loaches, suckers), Characiformes (tetras, piranhas), Siluriformes (catfishes), and Gymnotiformes (electric eels). These otophysan fishes share modifications of the inner ear, gas bladder, and of the four or five anterior vertebrae and associated elements together called the Weberian apparatus [3]. In a broader phylogenetic context, otophysan fishes represent one of the clades in Subdivision Otocephala [5] along with the orders Gonorynchiformes (= Anotophysi) [6] and Alepocephaliformes [5,7]. Otocephala itself represents a sister clade of Subdivision Euteleostei [8] comprising numerous marine species, including those of Series Percomorpha $[3,9,10]$.

Although recent molecular phylogenetic studies have increased our understanding of the interfamilial relationships within each of the four otophysan orders remarkably (Cypriniformes [11-18]; Characiformes $[19,20]$; Siluriformes [21,22]; Gymnotiformes [23,24]), few studies have specifically addressed the interordinal relationships of the otophysans. Following the advent of cladistic methods [25,26], Fink and Fink [27] proposed the first explicit hypothesis of the otophysan phylogenies (Figure 2A) based on examinations of 127 morphological characters. Subsequently Dimmick and Larson [28] corroborated this hypothesis based on the combined morphological and molecular data (nuclear and mitochondrial rDNA sequences), although the molecular data alone provided a different hypothesis (Figure $2 \mathrm{~B}$ ). The latter hypothesis is congruent with that reported by Saitoh et al. [4] who performed a maximum likelihood (ML) analysis using whole mitogenome sequences from major otophysan lineages. Monophyly of Characiformes, however, was not recovered in the two publications of Ortí and Meyer, who analyzed characiphysan phylogenies using nuclear ependymin [29] (Figure 2C) and mitochondrial rDNA sequences [19] (Figure 2D), which is also true for Peng et al. [30] and the results of maximum parsimony analysis reported by Saitoh et al. [4] but in a different manner (Figure 2E). Notably, more recent molecular phylogenetic studies based on both

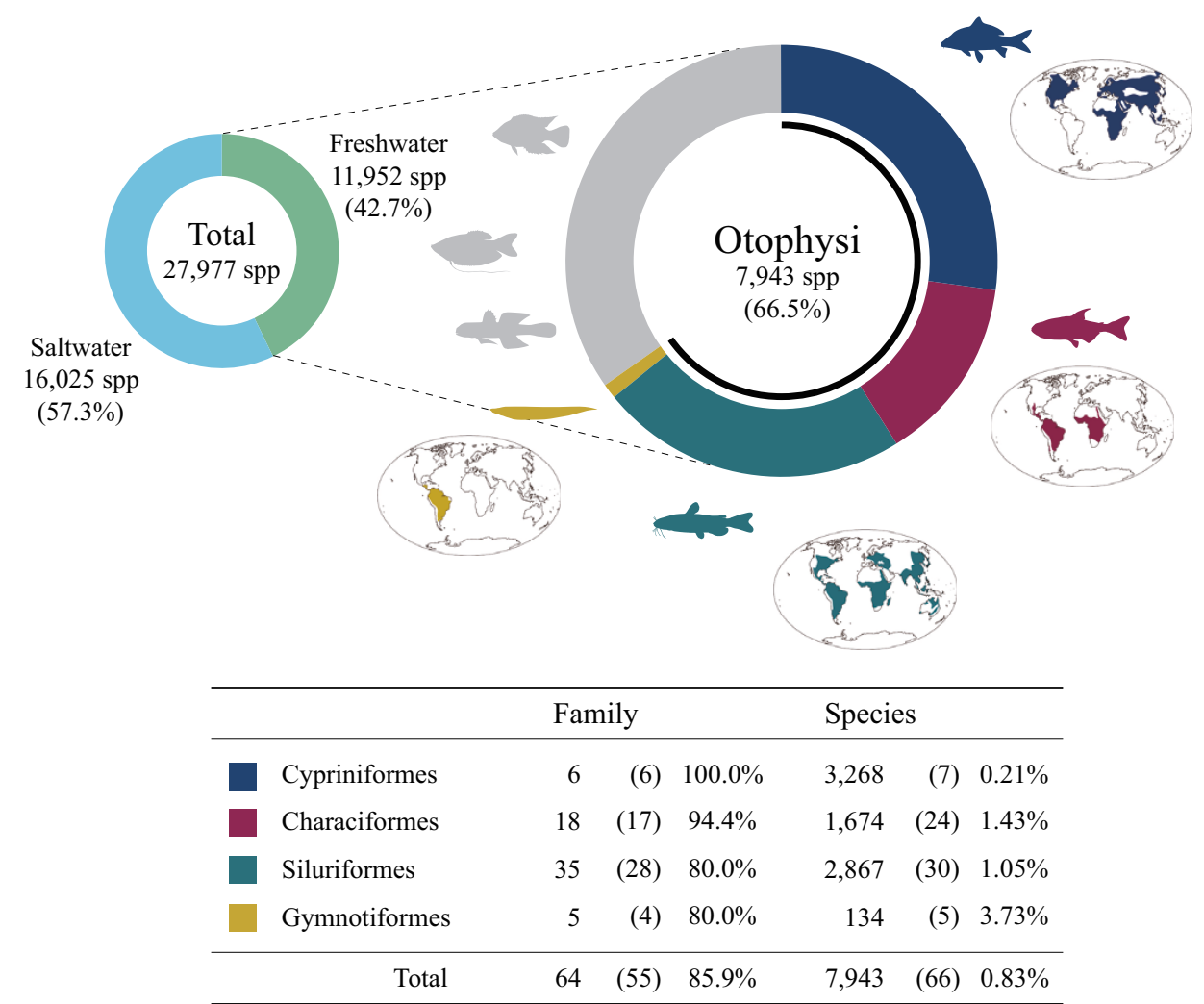

Figure 1 Species diversity and geographic distributions of otophysans [3]. Numbers of families and species for the four orders are indicated below the pie charts with those sampled in the present study in parentheses. 


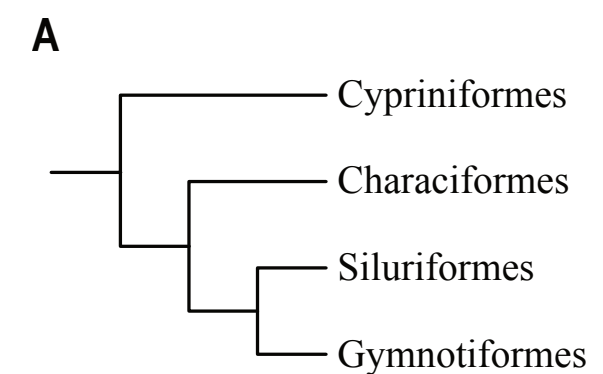

C

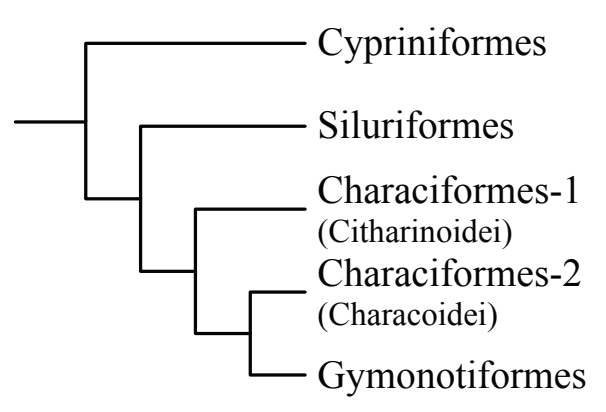

E

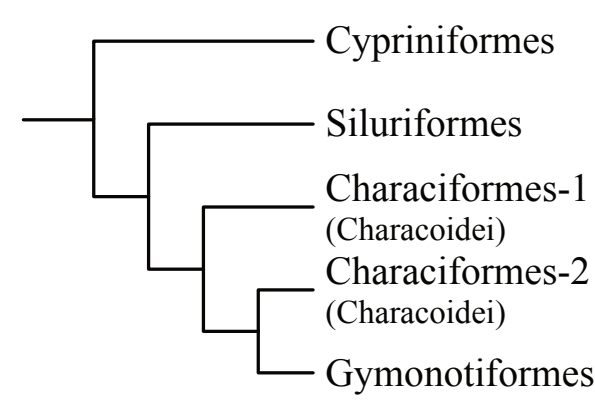

B
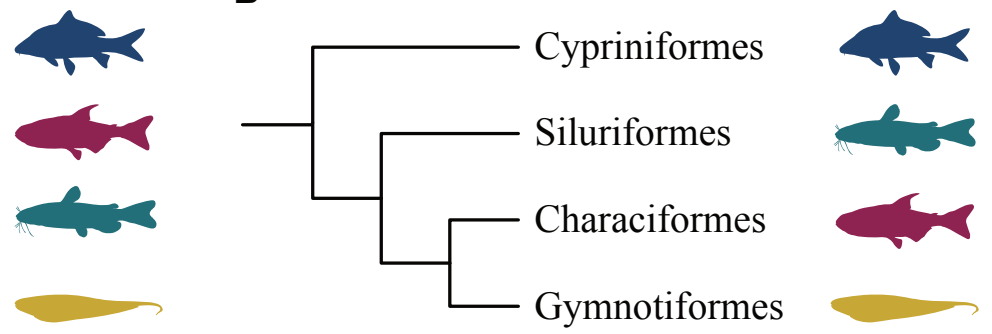

D
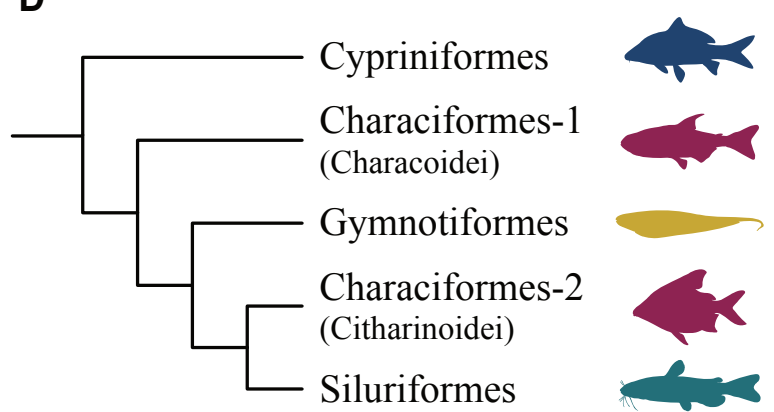

$\mathbf{F}$
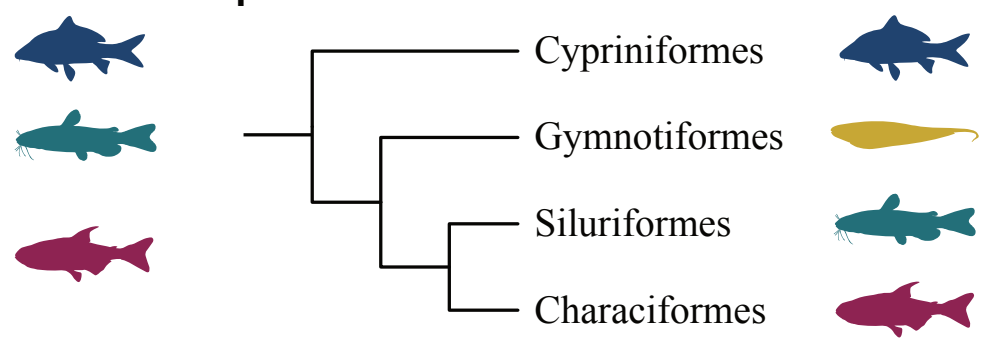
Characiformes

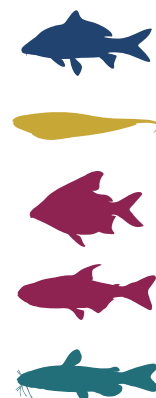

This study

Figure 2 Alternative phylogenetic hypotheses of the otophysans. A) Morphology-based hypothesis of Fink and Fink [27] and that of Dimmick and Larson [28] based on combined morphological and molecular data; Molecular-based hypotheses of B) Dimmick and Larson [28] and Saitoh et al. (maximum likelihood analysis) [4]; C) Ortí and Meyer [29]; D) Ortí and Meyer [19]; E) Saitoh et al. (maximum parsimony analysis; the study includes only two characoids) [4] and Peng et al. [30]; F) Lavoué et al. [6] and Poulsen et al. [5] and Li et al. [31]; and G) this study. 
whole mitogenomes [5,6] and nuclear genes [31] have converged to an additional hypothesis (Figure $2 \mathrm{~F}$; but see [24]), although these studies did not specifically address the resolution of otophysan phylogenies. Thus, no consensus exists regarding the relationships among major otophysan lineages with the exception of the most basal position of Cypriniformes. Nevertheless, these molecular studies lacked sufficient taxonomic and/ or character sampling (Table 1) to resolve higher-level relationships among otophysan lineages, which exhibit enormous taxonomic diversity (Figure 1). Actually none of the previous studies sampled longer nucleotide sequences (e.g., $>5000 \mathrm{bp}$ ) from more than three species across all of the four orders (Table 1).

In Otophysi, a great deal of attention has been paid to the biogeographic history that has shaped the current distribution patterns. Indeed, contrasting patterns in the geographic distributions of modern otophysans (Gondwanan vs. Laurasian vs. Pangaean distributions; Figure 1), the general acceptance of plate tectonics and continental drift as explanatory factors for dispersal across land connections and/or as a causal mechanism of vicariant speciation, and the presumed designation of the ostariophysans (Otophysi + Gonorynchiformes) as "primary freshwater fishes" (with dispersal across oceans being unlikely) together led many authors to propose evolutionary scenarios that attempt to identify a center of origin and dispersal routes through land connections based on various assumptions [4,12,27,32-37]. Reconstruction of the history of otophysan diversification (e.g., the history of the modern familial diversification), however, remains unchallenged, apparently because of poor representation in the fossil record before the Cenozoic period [24,38-41], a huge extant taxonomic diversity encompassing over 7943 species placed in 64 families and 1068 genera [3], and the absence of an adequate timescale for the phylogenies across major lineages (but see [30]). Indeed, in a review of the early radiation of teleosts, Arratia [42] stated “... the enormous radiation of some modern groups such as otophysans, atherinomorphs, perciforms, etc. is missing a historical framework."

To provide an overview of the history of modern otophysan diversification within the broad context of the evolutionary history of ray-finned fishes (Actinopterygii), we assembled whole mitochondrial genome (mitogenome) sequences from 66 otophysans (including 51 newly determined sequences), representing 55 of the 64 currently recognized families (86\%; Figure 1). The 66 sequences were concatenated with those from 44 outgroup species for a total of 110 species and unambiguously aligned sequences (9923 bp excluding quickly saturated third codon positions) were subjected to phylogenetic analysis and a relaxed-clock Bayesian divergence time estimation. The resultant timetree suggests that the modern otophysan diversity has been shaped through the two consecutive mass extinction events on the Pangaea supercontinent and subsequent radiations during the Jurassic through the early Cretaceous.

\section{Methods}

\section{Taxonomic sampling}

In addition to the 54 fish species used in Azuma et al. [43], 66 otophysans were newly added in this study, making a total of 110 species analyzed (Table 2). The 54 outgroup species encompass the whole actinopterygians (ray-finned fishes) from the bottom to the top of the tree and the 66 otophysans include 55 of the 64 currently recognized families (Figure 1 ).

Table 1 A summary of character and taxon sampling in the previous molecular phylogenetic studies that include the four otophysan orders

\begin{tabular}{|c|c|c|c|c|c|c|c|c|c|}
\hline \multirow[t]{2}{*}{ Study } & \multirow[t]{2}{*}{ Figure 2} & \multirow[t]{2}{*}{ Marker $^{a}$} & \multirow[t]{2}{*}{ Length (bp) } & \multirow[t]{2}{*}{ Cyp } & \multirow[t]{2}{*}{ Gym } & \multicolumn{2}{|r|}{ Cha } & \multirow[t]{2}{*}{ Sil } & \multirow[t]{2}{*}{ Total } \\
\hline & & & & & & Cith & Char & & \\
\hline Dimmick \& Larson [28] & $B$ & $\mathrm{nc}+\mathrm{mt}$ rDNA & 2477 & 2 & 2 & 1 & 1 & 3 & 9 \\
\hline Ortí \& Meyer [29] & C & nc ependymin & 588 & 3 & 2 & 1 & 12 & 4 & 22 \\
\hline Ortí \& Meyer [19] & $\mathrm{D}$ & mt rDNA & 870 & 2 & 3 & 2 & 11 & 4 & 22 \\
\hline Saitoh et al. [4] & $B, E$ & mt genome & 8096 & 7 & 2 & 0 & 2 & 2 & 13 \\
\hline Lavoué et al. [6] & $\mathrm{F}$ & mt genome & 10395 & 7 & 2 & 0 & 2 & 2 & 13 \\
\hline Peng et al. [30] & $E$ & mt genome & 6198 & 8 & 2 & 0 & 2 & 5 & 17 \\
\hline Li et al. [31] & $\mathrm{F}$ & 10 nc genes & 7995 & 3 & 1 & 0 & 1 & 1 & 6 \\
\hline Poulsen et al. [5] & $F$ & mt genome & 11076 & 14 & 2 & 0 & 2 & 5 & 23 \\
\hline Alves-Gomes [24] & $A$ & mt rDNA & 701 & 15 & 15 & 2 & 13 & 15 & 60 \\
\hline This study & G & mt genome & 9923 & 7 & 5 & 3 & 21 & 30 & 66 \\
\hline This study & G & 10 nc genes & 7995 & 3 & 2 & 1 & 2 & 2 & 10 \\
\hline
\end{tabular}

Abbreviations for orders and suborders: Cyp = Cypriniformes; Gym = Gymnotiformes; Cha = Characiformes; Sil = Siluriformes; Cith = Citharinoidei; Char = Characoidei

${ }^{\mathrm{a}} \mathrm{nc}=$ nuclear $; \mathrm{mt}=$ mitochondrial. 
Table 2 List of the species used in this study

\begin{tabular}{|c|c|c|c|}
\hline Order/suborder/superfamily ${ }^{a}$ & Family & Species $^{\mathbf{b}}$ & Accession No. $^{c}$ \\
\hline \multicolumn{4}{|l|}{ Outgroup } \\
\hline Coelacanthiformes & Latimeriidae & Latimeria menadoensis & AP006858 \\
\hline Ceratodontiformes & Ceratodontidae & Neoceratodus forsteri & AJ584642 \\
\hline \multirow[t]{3}{*}{ Polypteriformes } & Polypteridae & Polypterus ornatipinnis & AP004351 \\
\hline & & Polypterus senegalus & AP004352 \\
\hline & & Erpetoichthys calabaricus & AP004350 \\
\hline \multirow[t]{3}{*}{ Acipenseriformes } & Acipenseridae & Acipenser transmontanus & AB042837 \\
\hline & & Scaphirhynchus cf. albus & AP004354 \\
\hline & Polyodontidae & Polyodon spathula & AP004353 \\
\hline \multirow[t]{2}{*}{ Lepisosteiformes } & Lepisosteidae & Lepisosteus oculatus & AB042861 \\
\hline & & Atractosteus spatula & AP004355 \\
\hline Amiiformes & Amiidae & Amia calva & AB042952 \\
\hline Hiodontiformes & Hiodontidae & Hiodon alosoides & AP004356 \\
\hline \multirow[t]{2}{*}{ Osteoglossiformes } & Osteoglossidae & Osteoglossum bicirrhosum & AB043025 \\
\hline & & Pantodon buchholzi & AB043068 \\
\hline Albuliformes & Notacanthidae & Notacanthus chemnitzi & AP002975 \\
\hline \multirow[t]{3}{*}{ Anguillformes } & Anguillidae & Anguilla japonica & AB038556 \\
\hline & Muraenidae & Gymnothorax kidako & AP002976 \\
\hline & Congridae & Conger myriaster & AB038381 \\
\hline \multirow[t]{3}{*}{ Clupeiformes } & Denticipitidae & Denticeps clupeoides & AP007276 \\
\hline & Engraulidae & Engraulis japonicus & AB040676 \\
\hline & Clupeidae & Sardinops melanostictus & AB032554 \\
\hline \multirow[t]{4}{*}{ Gonorynchiformes } & Chanidae & Chanos chaos & AB054133 \\
\hline & Gonorynchidae & Gonorynchus greyi & AB054134 \\
\hline & Kneriidae & Kneria sp. & AF007278 \\
\hline & Phractolaemidae & Phractolaemus ansorgii & AB070243 \\
\hline \multirow[t]{3}{*}{ Alepocephaliformes } & Platytroctidae & Platytroctes apus & AP004107 \\
\hline & Bathylaconidae & Herwigia kreffti & AP009582 \\
\hline & Alepocephalidae & Alepocephalus tenebrosus & AP004100 \\
\hline Salmoniformes & Salmonidae & Salmo salar & U12143 \\
\hline Esociformes & Esocidae & Esox lucius & AP004103 \\
\hline Polymixiiformes & Polymixiidae & Polymixia japonica & AB034826 \\
\hline Gadiformes & Gadidae & Gadus morhua & X99772 \\
\hline \multirow[t]{10}{*}{ Perciformes } & Cichlidae & Oreochromis sp. & AP009126 \\
\hline & & Neolamprologus brichardi & AP006014 \\
\hline & & Tropheus duboisi & AP006015 \\
\hline & & Astronotus ocellatus & AP009127 \\
\hline & & Paretroplus maculatus & AP009504 \\
\hline & & Etroplus maculatus & AP009505 \\
\hline & & Hypselecara temporalis & AP009506 \\
\hline & & Ptychochromoides katria & AP009507 \\
\hline & & Paratilapia polleni & AP009508 \\
\hline & & Tylochromis polylepis & AP009509 \\
\hline \multirow[t]{2}{*}{ Tetraodontiformes } & Tetraodontidae & Takifugu rubripes & AJ421455 \\
\hline & & Tetraodon nigroviridis & AP006046 \\
\hline \multicolumn{4}{|l|}{ Ingroup } \\
\hline \multicolumn{4}{|l|}{ Cypriniformes } \\
\hline \multirow[t]{3}{*}{ Cyprinoidea } & Cyprinidae & Cyprinus carpio & X61010 \\
\hline & & Danio rerio & AC024175 \\
\hline & Psilorhynchidae & Psilorhynchus homaloptera & DQ026436 \\
\hline Cobitoidea & Gyrinocheilidae & Gyrinocheilus aymonieri & AB242164 \\
\hline
\end{tabular}


Table 2 List of the species used in this study (Continued)

\begin{tabular}{|c|c|c|c|}
\hline & Catostomidae & Catostomus commersonii & AB127394 \\
\hline & Cobitidae & Cobitis striata & AB054125 \\
\hline & Balitoridae & Formosania lacustre & M91245 \\
\hline \multicolumn{4}{|l|}{ Characiformes } \\
\hline \multirow[t]{3}{*}{ Citharinoidei } & Distichodontidae & Distichodus sexfasciatus & $\mathrm{AB} 070242^{* *}$ \\
\hline & & Ichthyborus sp. & AP011993** \\
\hline & Citharinidae & Citharinus congicus* & AP011985** \\
\hline \multirow[t]{21}{*}{ Characoidei } & Parodontidae & Parodon affinis & AP011998** \\
\hline & Curimatidae & Curimatopsis evelynae & AP011988** \\
\hline & Anostomidae & Leporinus affinis & AP011994** \\
\hline & Chilodontidae & Chilodus punctatus & AP011984** \\
\hline & Crenuchidae & Crenuchus spilurus & AP011986** \\
\hline & Hemiodontidae & Hemiodopsis gracilis & AP011990** \\
\hline & Alestidae & Micralestes sp. & AP011996** \\
\hline & & Phenacogrammus interruptus & AB054129 \\
\hline & Gasteropelecidae & Carnegiella strigata & AP011983** \\
\hline & Characidae & Astyanax mexicanus & AP011982** \\
\hline & & Chalceus macrolepidotus & AB054130 \\
\hline & & Myleus sp. & AP011997** \\
\hline & & Paracheirodon innesi & AP011999** \\
\hline & & Pygocentrus nattereri & AP012000** \\
\hline & Acestrorhynchidae & Acestrorhynchus sp. & AP011981** \\
\hline & Cynodontidae & Hydrolycus scomberoides & AP011989** \\
\hline & Erythrinidae & Hoplias malabaricus & AP011992** \\
\hline & Lebiasinidae & Lebiasina astrigata & AP011995** \\
\hline & Ctenoluciidae & Boulengerella maculata & AB070207 \\
\hline & & Ctenolucius hujeta* & AP011987** \\
\hline & Hepsetidae & Hepsetus odoe & AP011991** \\
\hline \multicolumn{4}{|l|}{ Siluriformes } \\
\hline Diplomystoidea & Diplomystidae & Diplomystes nahuelbutaensis & AP012011** \\
\hline \multirow[t]{2}{*}{ Cetopsoidea } & Cetopsidae & Cetopsidium sp. & AP012007** \\
\hline & & Helogenes marmoratus* & AP012014** \\
\hline \multirow[t]{5}{*}{ Loricaroidea } & Amphiliidae & Amphilius sp. & AP012002** \\
\hline & Tricomycteridae & Trichomycterus areolatus & AP012026** \\
\hline & Callichthyidae & Corydoras rabauti & AB054128 \\
\hline & Astroblepidae & Astroblepus sp. & AP012004** \\
\hline & Loricariidae & Pterygoplichthys disjunctivus & AP012021** \\
\hline \multirow[t]{3}{*}{ Sisoroidea } & Amblycipitidae & Liobagrus reinii & AP012015** \\
\hline & Erethistidae & Hara jerdoni & AP012012** \\
\hline & Aspredinidae & Bunocephalus coracoideus & AP012006** \\
\hline Cranoglanoidea & Cranoglanididae & Cranoglanis bouderius & AY898626 \\
\hline Ictaluroidea & Ictaluridae & Ictalurus punctatus & AF482987 \\
\hline \multirow[t]{4}{*}{ Doradoidea } & Mochokidae & Synodontis schoutedeni & AP012023** \\
\hline & Doradidae & Amblydoras gonzalezi & AP012001** \\
\hline & Auchenipteridae & Tatia pergiae & AP012024** \\
\hline & & Tetranematichthys quadrifilis & AP012025** \\
\hline \multirow[t]{6}{*}{ Siluroidea } & Siluridae & Silurus asotus & AP012022** \\
\hline & Malapteruridae & Malapterurus electricus & AP012016** \\
\hline & Auchenoglanididae & Auchenoglanis occidentalis & AP012005** \\
\hline & Chacidae & Chaca bankanensis & AP012008** \\
\hline & Plotosidae & Plotosus japonicus & AP012020** \\
\hline & Clariidae & Clarias sp. & AP012010** \\
\hline
\end{tabular}


Table $\mathbf{2}$ List of the species used in this study (Continued)

\begin{tabular}{|c|c|c|c|}
\hline & Heteropneustidae & Heteropneustes fossilis & AP012013** \\
\hline \multirow[t]{6}{*}{ Bagroidea } & Claroteidae & Chrysichthys sp. & AP012009** \\
\hline & Ariidae & Sciades seemanni & AP012003** \\
\hline & Schilbeidae & Pareutropius debauwi & AP012017** \\
\hline & Pangasiidae & Pangasius larnaudii & AP012018** \\
\hline & Bagridae & Pseudobagrus tokiensis & AB054132 \\
\hline & Pimelodidae & Pimelodus pictus & AP012019** \\
\hline \multicolumn{4}{|l|}{ Gymnotiformes } \\
\hline \multirow[t]{2}{*}{ Gymnotoidei } & Gymnotidae & Electrophorus electricus & AP011978** \\
\hline & & Gymnotus carapo* & AP011979** \\
\hline \multirow[t]{3}{*}{ Sternopygoidei } & Rhamphichthyidae & Gymnorhamphichthys sp. & AP011980** \\
\hline & Sternopygidae & Eigenmannia sp. & AB054131 \\
\hline & Apteronotidae & Apteronotus albifrons & AB054132 \\
\hline
\end{tabular}

\section{Specimens and DNA extraction}

A portion of epaxial musculature or pectoral fins $(\sim 0.25$ g) from fresh specimens of each species was excised and the tissue was immediately preserved in $99.5 \%$ ethanol. Total genomic DNA from the ethanol-preserved tissue was extracted using DNeasy (Qiagen) and Aquapure genomic DNA isolation kit (Bio-Rad Laboratories, Inc.) in accordance with the respective manufacturer's protocols, or the standard phenol-chloroform method as described in Asahida et al. [44].

\section{PCR and sequencing}

Whole mitogenome sequences of the 51 otophysans (double asterisks in Table 2) were determined using a combination of long and short PCR methods developed by Miya and Nishida [45]. Briefly, the mitogenomes of the 51 otophysans in their entirety were amplified using a long PCR technique [46] in two or three reactions. Dilution of the long PCR products with TE buffer (1:10 to 100 depending on the concentration of the long PCR products) served as templates for subsequent short PCRs. Standard sets of fish-versatile primers (and species-specific primers if necessary) were used for short PCRs to amplify contiguous overlapping segments of the entire mitogenome for each otophysan species. The short PCR products were purified using the Exosap-IT enzyme (GE Healthcare Bio-Sciences Corp.) and subsequently sequenced with dye-labeled terminators (BigDye terminator ver. 1.1/3.1; Applied Biosystems) and the primers used in the short PCRs. Sequencing reactions were conducted according to the manufacturer's instructions, followed by electrophoresis on an ABI Prism 377, 3100, or 3130 DNA sequencer (Applied Biosystems). A list of PCR primers used in this study is available from $\mathrm{MNa}$ upon request.
In some cases when multiple bands were amplified during short PCRs, we conducted subcloning using MinElute (Qiagen), pGEM-T Easy Vector Systems (Promega), and Z-competent E. coli (ZYMO Research), in accordance with the manufactures' protocols. To avoid PCR errors, we sequenced eight clones for each fragment using SP6 and T7 primers.

\section{Sequence editing and alignment}

Mitogenome sequences from the 66 otophysans were concatenated with the pre-aligned sequences used in Azuma et al. [43] in FASTA format and subjected to multiple alignment using MAFFT ver. 6.707 [47]. The aligned sequences were imported into MacClade ver. 4.08 [48] and the resulting gaps in the aligned sequences were manually removed to correctly reproduce the alignment used by Azuma et al. [43]. All the resulting positions with gaps were removed, so the final data set consisted of 6904 positions from the first and second codon positions of the 12 protein-coding genes (excluding the ND6 gene because of its heterogeneous base composition and poor phylogenetic performance [49]), 1622 positions from the two rRNA genes, and 1397 positions from the 22 tRNA genes (total 9923 positions) (designated as $12_{n} \mathrm{RT}_{\mathrm{n}}$ : where 1 , $2, \mathrm{R}$ and $\mathrm{T}$ represent 1 st codon position, 2 nd codon position, rRNA gene and tRNA gene, respectively, and the subscript " $n$ " denotes nucleotides). The third codon positions of the protein-coding genes were excluded from the data set because of the extremely high substitution rates (and the resulting multiple hits) and heterogeneous base composition as sources of systematic noise in phylogenetic analysis at this taxonomic level $[49,50]$ and overestimation of divergence time $[51,52]$. The aligned sequences are available from 
TreeBase with the following URL (http://purl.org/ phylo/treebase/phylows/study/TB2:S11469).

To investigate the relationships within the otophysans, we also created an additional four data sets that treated 12 protein-coding genes differently. The first three data sets considered only transversional changes in the first and/or third codon positions by converting purine $(\mathrm{A} / \mathrm{G})$ and pyrimidine $(\mathrm{C} / \mathrm{T})$ nucleotides to $\mathrm{A}$ and $\mathrm{C}$, respectively $\left(1_{r} 2_{n} R_{n} T_{n}, 12_{n} 3_{r} R T_{n}, 1_{r} 2_{n} 3_{r} R T_{n}\right.$ : where the subscript " $\mathrm{r}$ " denotes a modified RY-coding following Saitoh et al. [11]). The transitional changes in the first codon positions are somewhat saturated among distantly related taxa [49], and the first data set $\left(1_{r} 2_{n} R T_{n}\right)$ was expected to reduce phylogenetic noise from the original data set $\left(12_{n} R T_{n}\right)$. The second data set $\left(12_{n} 3_{r} R T_{n}\right)$ added the RY-coded third codon positions to the original data set, which was expected to increase phylogenetic signals and was predominantly used to resolve interrelationships within the Cypriniformes [11,12], one of the major otophysan clades (Figure 1). The third data set $\left(1_{r} 2_{n} 3_{r} T_{n}\right)$ removed transitional changes in the first codon positions from the second data set. The last data set converted protein-coding genes into amino acids (designated as $123_{\mathrm{a}} \mathrm{RT}_{\mathrm{n}}$ ) to explore the utility of these sequences in resolving otophysan taxa. Only 66 otophysans plus 12 outgroup species (4 gonorynchiforms +3 clupeiforms +3 alepocephaliforms +2 anguillifoms) were used in these additional data sets to minimize the computation time.

\section{Phylogenetic analysis}

Unambiguously aligned sequences were divided into three to five partitions depending on the data sets (three partitions in the $123_{\mathrm{a}} \mathrm{RT}_{\mathrm{n}}$ data set, four partitions in the $12_{n} \mathrm{RT}_{\mathrm{n}}$ and $1_{\mathrm{r}} 2_{\mathrm{n}} \mathrm{RT}_{\mathrm{n}}$ data sets, and five partitions in the $12_{\mathrm{n}} 3_{\mathrm{r}} \mathrm{RT} \mathrm{T}_{\mathrm{n}}$ and $1_{\mathrm{r}} 2_{\mathrm{n}} 3_{\mathrm{r}} \mathrm{RT}_{\mathrm{n}}$ data sets) and subjected to ML analysis. We used RAxML ver. 7.2.8 [53] because it is the only ML-based software that can handle large data sets with data partitioning. A general time reversible model (GTR) [54] with sites following a discrete gamma distribution $(\Gamma)$ and some sites invariable (I) was selected as the best model of nucleotide sequence evolution by Modeltest ver. 3.7 [55] using the Akaike information criterion (AIC). For amino acid sequences, the MTREV model [56] with sites following a discrete gamma distribution $(\Gamma)$ and some sites invariable (I) was used. We performed a rapid bootstrap (BS) analysis using this model $(\mathrm{GTR}+\Gamma+\mathrm{I})$ with 1000 replications (-f a option). This performs BS analysis using GTRCAT, which is a GTR approximation with optimization of individual per-site substitution rates and classification of these individual rates into a certain number of rate categories. After implementing the BS analysis, the program uses every fifth BS tree as a starting point for another
ML search using the GTR $+\Gamma+$ I model of sequence evolution and saves the top 10 best-scoring ML trees (fast ML searches). Finally, RAxML calculates more correct likelihood scores (slow ML searches) for those 10 trees and puts BS probabilities (BSPs) on the bestscoring ML tree.

\section{Evaluation of alternative hypotheses}

We manually created the constrained tree topologies with reference to the alternative hypotheses using MacClade and then performed RAxML analysis with each constraint using the -g option. We conducted fast bootstrapping with 100 replicates as described above, and the resulting best-scoring ML tree was considered as the constrained ML tree. The constrained and unconstrained ML trees (best-scoring ML tree without constraint) were used to compute the per-site log likelihood scores for each tree using the $-\mathrm{f} g$ option in RAxML and the output was subjected to CONSEL [57] analysis to calculate statistical significance of the differences in likelihood scores. Probabilities of alternative phylogenetic hypotheses were calculated using the likelihood-based approximately unbiased (AU) test [58] as implemented in CONSEL v.0.1k [57]. The $P$-values from this test are calculated using the multi-scale bootstrap technique and are less biased than those of conventional methods [57] such as the BS probability (BSP) [59], the Kishino-Hasegawa $(\mathrm{KH})$ test $[60]$ and the Shimodaira-Hasegawa $(\mathrm{SH})$ test [61].

\section{Supplementary analysis using nuclear genes}

To corroborate the novel relationships among major otophysan lineages obtained in this study (see below), we determined some of the putative single-copy nuclear gene sequences for the selected four otophysans (asterisks in Table 2) according to the methods described by Li et al. [31] (Table 3). We have added these sequences to the aligned data set used in Li et al. (available from http://www.treebase.org/treebase-web/home.html; newID: M3165) who studied actinopterygian phylogenies with 56 species (including three cypriniforms and three characiphysans), and the data set was subjected to partitioned ML analysis according to Kawahara et al. [62].

\section{Divergence time estimation}

A relaxed molecular clock Bayesian method implemented in the MCMCTREE program in PAML 4.4b [63] was used for dating analysis. We also attempted to use BEAST [64] for our data set, but MCMC samples failed to converge after $10^{8}$ chains. The best-scoring ML tree from the $12{ }_{n} \mathrm{RT}_{\mathrm{n}}$ data set was used for divergence time estimation. The ML estimates of branch lengths were obtained using BASEML and CODEML (in PAML) programs under the GTR $+\Gamma_{5}$ and MTREVF $+\Gamma_{5}$ 
Table 3 DNA accession numbers of the nuclear genes from the four characiphysans

\begin{tabular}{|c|c|c|c|c|}
\hline Gene & Citharinus congicus & Ctenolucius hujeta & Helogenes marmoratus & Gymnotus carapo \\
\hline$\overline{\text { zic1 }}$ & AB605470 & AB605476 & ------ & AB605488 \\
\hline myh6 & - & 一- & --—-二- & 一 \\
\hline PYR3 & -二- & -二- - & - - - & -——-— \\
\hline ptr & AB605467 & AB605473 & -——-— & AB605484 \\
\hline Tbr & AB605469 & AB605471 & AB605480 & AB605487 \\
\hline ENC1 & AB605465 & AB605474 & AB605477 & AB605481 \\
\hline Glyt & -— & -——- & 一 & AB605482 \\
\hline SH3PX3 & -二-二- & AB605474 & -二-二- & AB605485 \\
\hline plagl2 & AB605466 & AB605472 & AB605478 & AB605483 \\
\hline sreb2 & AB605468 & AB605475 & AB605479 & AB605486 \\
\hline
\end{tabular}

substitution models [54] for the $12_{n} \mathrm{RT}_{\mathrm{n}}$ and $123_{\mathrm{a}}$ data sets, respectively, with the gamma prior set at 0.5 . Two priors, the overall substitution rate (rgene gamma) and rate-drift parameter (sigma2 gamma), were set at $G(1,12.3)$ and $G(1,4.45)$ for the $12_{n} \mathrm{RT}_{\mathrm{n}}$ data set and $G(1,14.3)$ and $G(1,4.5)$ for the $123_{\mathrm{a}}$ data set, respectively, using the strict molecular clock assumption with $445 \mathrm{Ma}$ constraint to the divergence between Actinopterygii and Sarcopterygii (average of the upper and lower constraints for the node between ray-finned and lobe-finned fish; see Table 4). The independent-rates (IR) model [65] was used to specify the prior of rates among internal nodes (clock $=2$ in MCMCTREE). The IR model has been considered more appropriate in divergence time estimation than the autocorrelated-rates (AR) model in recent studies (see [66] and references therein), although additional analyses using AR model (clock $=3$ in MCMCTREE) were also performed for

Table 4 Time constraints used for divergence time estimation

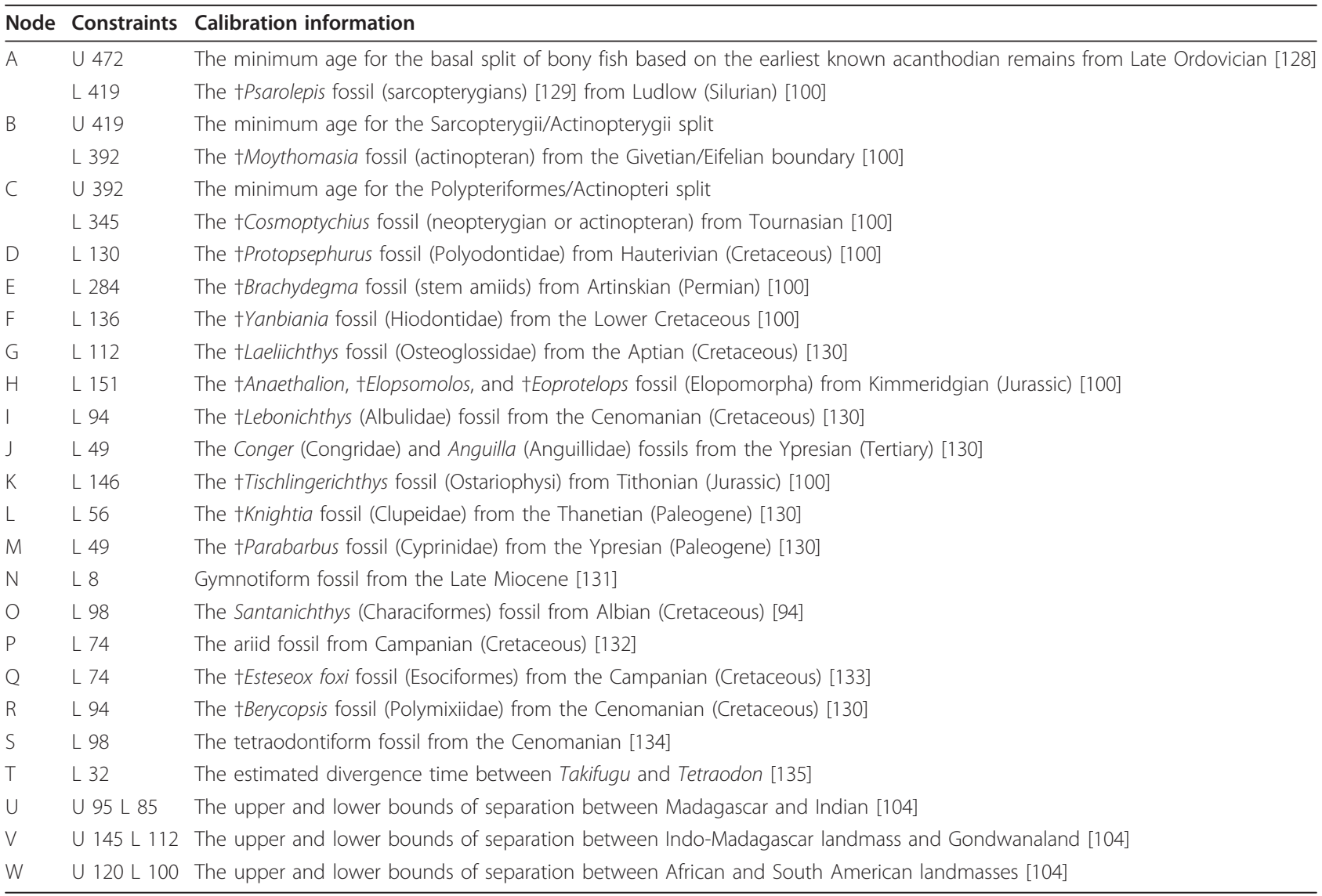


comparison. The parameters of the birth-death process for tree generation with species sampling [67] were fixed at $\lambda=\mu=1$ and $\rho=0$, so that the priors are similar to those used in the previous mitogenomic studies [43,68] using MULTIDIVTIME [69]. A loose maximum bound for the root was set at $<10.0(=1000 \mathrm{Ma})$.

The MCMCTREE program allows for minimum (lower) and maximum (upper) time constraints, and multiple calibration points have been argued to provide overall more realistic divergence time estimates [70]. Therefore we sought to obtain optimal phylogenetic coverage of calibration points across our tree, although we could set maximum constraints based on the fossil records only for the six nodes (Table 4). Other than these six nodes, 17 additional nodes were reasonably chosen to constraint their minimum ages only (total 29 time constraints for 23 nodes; Table 4). $A$ hard and softbound version of the program (MCMCTREE-HS) was used, so that probabilities of the true divergence time falling outside the minimum bounds are zero, but small but not zero for the maximum bounds [71]. All time constraints are provided in units of $100 \mathrm{Ma}$ (i.e., $1=100 \mathrm{Ma}$ ) because some of the model components in the Bayesian analysis are scalevariant [63]. The calibration nodes with minimal bound only were set as $L\left(t_{\min }\right)$ and those with both minimal and maximal bounds were set as $B\left(t_{\mathrm{min}}\right.$, $\left.t_{\max }\right)$. The former setting $(L)$ assumes a heavy-tailed density (nearly a flat prior) based on a truncated Cauchy distribution of $p=0.1$ and $c=1$ as the default [63] ("standard minimum-age constraints" [72]). We did not manipulate the two shape parameters of the truncated Cauchy distribution because of insufficient information with which to specify meaningful prior distributions for most otophysan diversification times.

MCMC approximation with a burn-in period of 10,000 cycles was obtained, and every 50 cycles was taken to create a total of 10,000 samples. To diagnose possible failure of the Markov chains to converge to their stationary distribution, we performed two replicate MCMC runs with two different random seeds for each analysis. MCMC samples from the two runs were combined after checking the distributions of parameter values using Tracer 1.5 (available from http://tree.bio. ed.ac.uk/software/tracer/). The number of samples $(20,000)$ was large enough to reach effective sample sizes (ESSs $>200$ ) for all parameters estimated in this study.

To evaluate the effects of topological uncertainties on divergence time estimation, we also conducted dating analyses with four of the 14 alternative topologies (four topologies with the second best $P$ value, the two worst $P$ values, plus a hypothesis advocated by Fink and Fink [27]).

\section{Tracing character evolution}

The ancestral habitat was reconstructed on the timetree under a ML optimality criterion using Mesquite ver. 2.71 [73]. The ML reconstruction methods found that the ancestral states maximizing the probability of the observed states would evolve under a stochastic model of evolution [74,75]. The Mk1 model ("Markov k-state 1 parameter model"), a k-state generalization of the JukesCantor model that corresponds to Lewis' Mk model [76], was used to trace the character evolution. Two character states were assigned to the terminal node: saltwater (character state 0 ) and freshwater (state 1).

\section{Results and Discussion}

\section{Genome organization}

Complete L-strand nucleotide sequences from the mitogenomes of the 51 species newly determined during this study were deposited in the DNA Data Bank of Japan (DDBJ), European Molecular Biology Laboratory (EMBL), and GenBank (Table 2). The genome content of the 51 species included two rRNA, 22 tRNA, and 13 protein-coding genes, plus the putative control region, as found in other vertebrates. Their gene arrangements were identical to the typical gene order of vertebrates.

\section{Interordinal/subordinal relationships}

Partitioned ML analysis based on 110 whole mitogenome sequences $\left(12_{n} \mathrm{RT}_{\mathrm{n}}\right.$ data set) resulted in a relatively well resolved tree, with approximately $70 \%$ of the internal branches supported by moderate to high (70-100\%) BSPs (Figure 3). Otocephala was confidently recovered as a monophyletic group (BSP $=100 \%$ ) and a clade containing two primarily marine orders (Clupeiformes and Alepocephaliformes) was sister to all other otocephalans. Gonorynchiformes was recovered as the sister group of Otophysi (BSP $=82 \%$ ) and monophyly of the latter was confidently recovered (BSP $=100 \%$; Figure 3 ), confirming the results of recent molecular studies $[5,7,31]$. Of the four orders within the otophysans, monophyletic Cypriniformes (BSP $=100 \%$ ) was a sister to a clade containing the remaining three orders collectively called Characiphysi $(\mathrm{BSP}=100 \%)$. Of the three characiphysan orders, Gymnotiformes and Siluriformes were confidently recovered as monophyletic groups (BSPs = $100 \%)$; however, one of the two suborders of Characiformes (Characoidei) was more closely related to Siluriformes (BSP $=79 \%$ ) than to the other (Citharinoidei). Statistical support for a clade containing these three lineages (Citharinoidei, Characoidei, Siluriformes), however, was not strong (BSP $=67 \%$ ).

Removal of transitional changes from the 1st codon positions $\left(1_{\mathrm{r}} 2_{\mathrm{n}} \mathrm{RT}_{\mathrm{n}}\right.$ data set), addition of transversional changes from the $3 \mathrm{rd}$ codon positions $\left(12_{\mathrm{n}} 3_{\mathrm{r}} \mathrm{RT}_{\mathrm{n}}\right.$ and $1_{\mathrm{r}} 2_{\mathrm{n}} 3_{\mathrm{r}} \mathrm{RT}_{\mathrm{n}}$ data sets), or conversion of the 


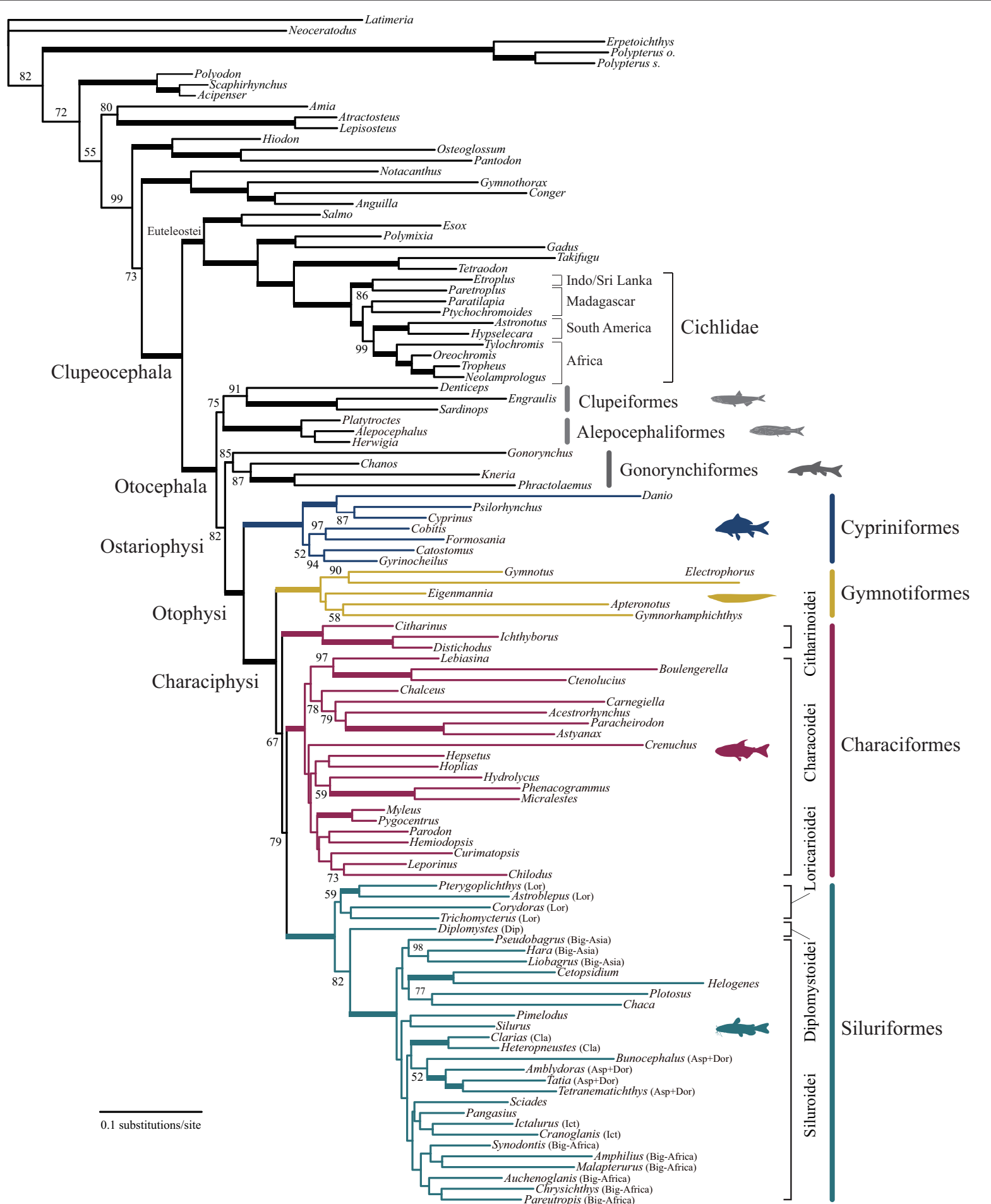

Figure 3 The best-scoring maximum-likelihood (ML) tree of the 66 otophysan and 44 outgroup species based on unambiguously aligned whole mitogenome sequences $\left(12_{n} \mathrm{RT}_{\mathrm{n}}\right.$ data set; 9923 positions). Numerals beside internal branches indicate bootstrap probabilities (BSPs) of $\geq 50 \%$ based on 1000 replicates. Thick lines indicate those internal branches with 100\% BSPs. Suprafamilial clades in Siluriformes reported by Sullivan et al. [21] are denoted as follows (abbreviations in parentheses): "Big Asia", "Claroidea" (Cla), "Aspredinidae + Doradoidea" (Asp + Dor), "Ictaluroidea" (Ict), and "Big Africa". 
protein-coding genes into amino acid sequences $\left(123_{\mathrm{a}} \mathrm{RT}_{\mathrm{n}}\right)$ together supported the novel relationships, although they did not improve the statistical support $(<50-67 \%$ BSPs for Citharinoidei + Characoidei + Siluriformes and 59-80\% BSPs for Characoidei + Siluriformes) (Figure 4).

Although taxonomic sampling from otophysans in the nuclear data set was far sparser than that of the mitogenomic data set (10 spp. vs. $66 \mathrm{spp}$.), and data were missing in the original as well as newly added sequences (approximately 25\% of the total positions; Table 3), partitioned ML analysis based on the 10 nuclear genes from the 60 species resulted in an identical tree topology to that of the mitogenomic tree regarding the relationships among the major otophysan lineages (Figure 5). Monophyly of Otophysi was confidently recovered at the apical position in Otocephala (BSP = $100 \%$ ), with Cypriniformes being a sister to all other otophysans. Within the Characiphysi, Gymnotiformes was a sister to other characiphysans and monophyly of Characiformes plus Siluriformes was supported with $100 \%$ BSP (67\% BSP in mitogenomic analysis; Figure 3), although the former was found to be paraphyletic, with Characoidei being more closely related to Siluriformes $(\mathrm{BSP}=52 \%)$ than to Citharinoidei.

Paraphyletic characiforms have been repeatedly recovered in previous molecular studies (Figure 2C-E) but in different manners. For example, Ortí and Meyer [29] assembled nuclear ependymin sequences (588 bp) from 22 otophysans to explore the phylogenetic utility of this gene and found that characoids were more closely related to Gymnotiformes than to a citharinoid (Distichodus) (Figure 2C). To investigate the characiform radiation, Ortí and Meyer [19] used partial mitochondrial rDNA sequences $(870 \mathrm{bp})$ as phylogenetic markers and observed that two citharinoids (Distichodus and Citharinus) were more closely related to Siluriformes than to characoids (Figure 2D). Although analyses of whole mitogenome sequences by Saitoh et al. [4] (maximum parsimony analysis of $8096 \mathrm{bp}$ ) and Peng et al. [30] (6198 bp) did not include citharinoids, one of the two characoids were more closely related to either Siluriformes or Gymnotiformes than to its own order (Figure $2 \mathrm{E})$. These relationships, however, received weak statistical support ( $<50 \%$ BSPs) and alternative tree topologies could not be rejected $[4,19,29]$.

Monophyly of Characiformes should be addressed in relation to the other two characiphysan orders. Accordingly, we evaluated the likelihoods of alternative hypotheses among four major characiphysan lineages (Gymnotiformes, Citharinoidei, Characoidei, Siluriformes) using the AU test (Table 5). Of the 15 possible tree topologies based on the mitogenomic data, AU tests confidently rejected only three that commonly included the monophyly of Characoidei plus Gymnotiformes $(P=0.001-0.030$; Table 5$)$, with likelihoods of the other 12 topologies ranging from 0.051 to 0.702 . Moreover, AU tests based on the nuclear data more confidently rejected 12 tree topologies $(P=0.000-0.006$; Table 6). For either marker, however, AU tests could not reject all of those topologies that included monophyletic Characiformes, and this issue therefore remains unanswered even in the molecular phylogenetic context. Apparently the two deep-branching lineages in the characiforms (Citharinoidei and Characoidei) make it difficult to resolve their relationships with Siluriformes even with the large data sets used in this study. Also we expect that future uses of newly developed models accounting for site-specific modulations of the aminoacid replacement process, such as the CAT mixture model [77] implemented in PhyloBayes [78], may result in more clear resolution of the characiphysan phylogenies. Note that monophyletic Characiformes was well accepted and seemingly uncontroversial on a morphological basis $[27,79-81]$.

\section{Interfamilial relationships}

Interfamilial relationships within each of the four major lineages are outside the scope of this study because taxonomic sampling is still sparse and requires at least several distantly related genera from the same family to reconstruct more reliable trees. Nevertheless, brief comparisons with previous studies are useful to direct future research.

In Cypriniformes, monophyly of one of the two superfamilies (Cyprinoidea) was consistently recovered, while another superfamily (Cobitoidea) has been variously recovered as mono- or paraphyletic depending on the data treatment (most notably that of the third codon position) even within some of the same studies [11-17]. An enigmatic Psilorhynchus (placed in its own family Psilorhynchidae) is nested within the cyprinid lineage (Cyprinus + Danio; Figure 3), rendering Cyprinidae paraphyletic as reported previously $[15,17,18]$.

In Gymnotiformes, a sister group relationship between two gymnotids (Electrophorus and Gymnotus) was confidently recovered (BSP $=90 \%$ ), but other portions of the tree were weakly supported (BSPs $\leq 58 \%$; Figure 3 ) and do not warrant further comment. Such ambiguous interfamilial relationships have been reported in previous studies based on mitochondrial rDNA sequences [23,24].

In Citharinoidei, one of the two suborders of Characiformes, two distichodontid genera (Distichodus and Ichthyborus) formed a strongly supported monophyletic group (BSP $=100 \%)$, which was sister to a citharinid (Citharinus). These relationships have been consistently recovered in previous studies based on both morphological $[79,82]$ and molecular $[19,20,83]$ analyses. Within 


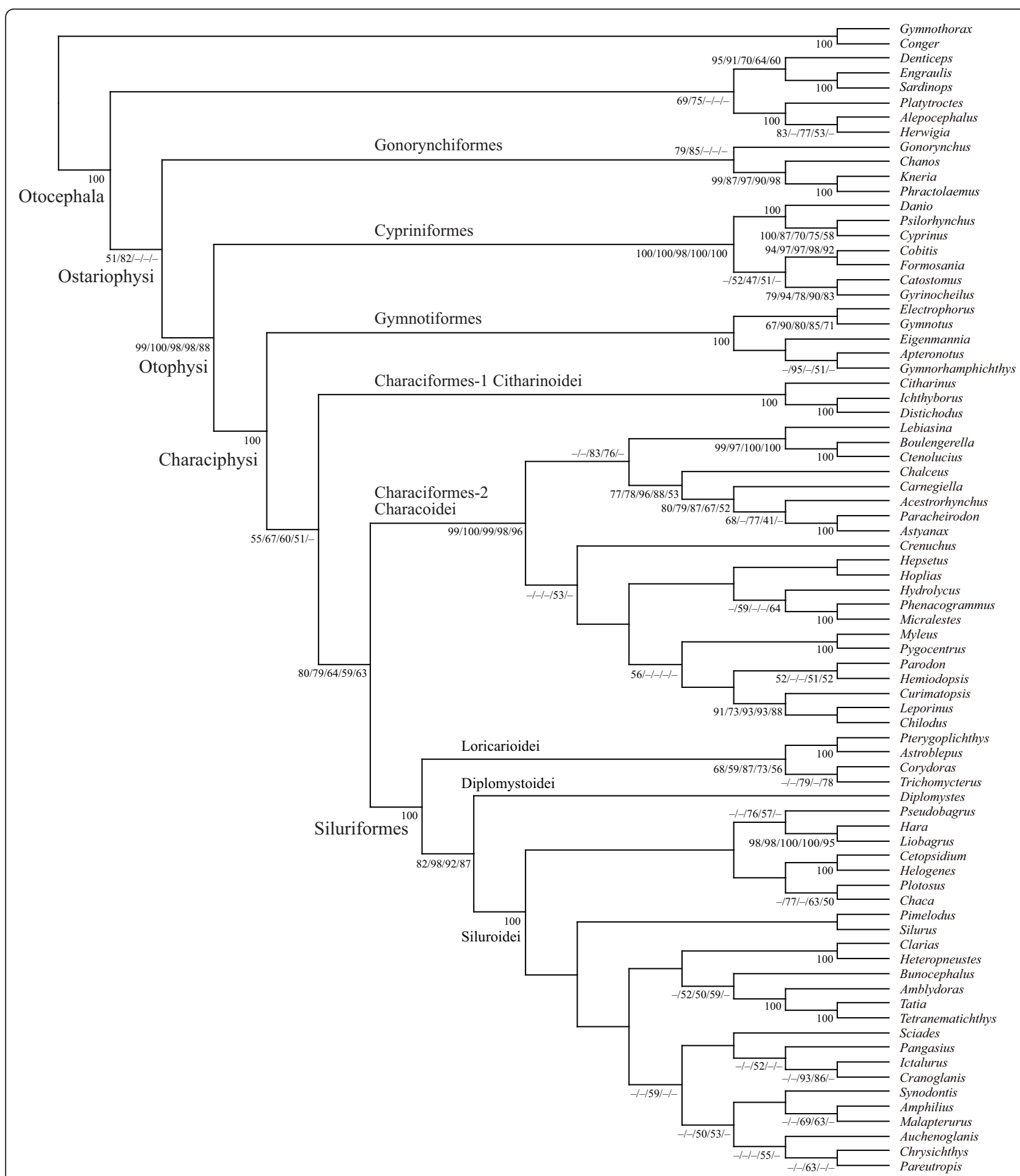

Figure 4 Bootstrap probabilities (BSPs) from RAxML analyses of the five different data sets that treated codon positions from the 12 protein-coding genes differently. The tree topology is derived from the RAxML analysis based on limited taxonomic sampling from the $12_{n} R T_{n}$ data set (all ingroup species +12 outgroup species). Numerals beside internal branches indicate BSPs of $\geq 50 \%$ based on 1000 replicates (BSPs of $1_{r} 2_{n} R T_{n} / 12_{n} R T_{n} / 1_{r} 2_{n} 3_{r} R T_{n} / 12_{n} 3_{r} R T_{n} / 123_{a} R T_{n}$ data sets from left to right). Single values denote the same BSPs obtained across the five data sets. 


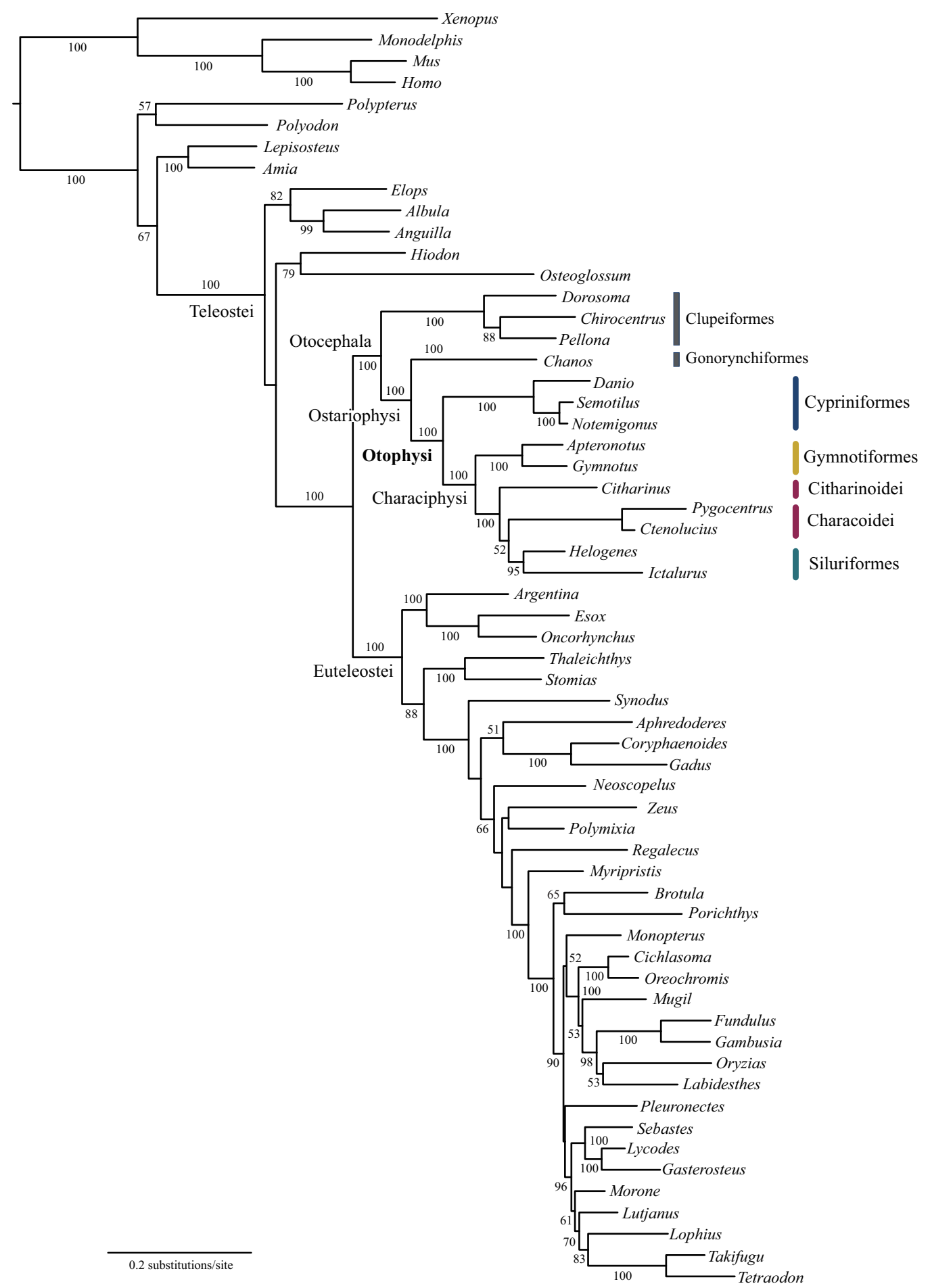

Figure 5 The best-scoring maximum-likelihood (ML) tree of the 10 otophysan and 50 outgroup species based on unambiguously aligned 10 nuclear gene sequences (8409 positions). Numerals beside internal branches indicate bootstrap probabilities (BSPs) of $\geq 50 \%$ based on 1000 replicates. 
Table 5 Results from AU-tests among 15 alternative tree topologies of the four major lineages derived from analysis of whole mitogenome sequences

\begin{tabular}{llll}
\hline Tree $^{\text {a }}$ & In $L$ & Diff $-\ln L$ & $\boldsymbol{P}^{\mathbf{b}}$ \\
\hline 1(Gym, (Cit, (Cha, Sil))) & -237742.581 & best & 0.702 \\
2(Gym, (Sil, (Cit, Cha))) & -237746.644 & 4.063 & 0.588 \\
3((Cit, Gym), (Cha, Sil)) & -237749.618 & 7.037 & 0.473 \\
4(Gym, (Cha, (Cit, Sil))) & -237749.793 & 7.212 & 0.400 \\
5(Cha, (Sil, (Cit, Gym))) & -237752.770 & 10.189 & 0.400 \\
6(Cit, (Gym, (Cha, Sil))) & -237752.584 & 10.003 & 0.362 \\
7(Cit, (Cha, (Sil, Gym))) & -237755.898 & 13.317 & 0.267 \\
8(Cha, (Cit, (Sil, Gym))) & -237755.375 & 12.794 & 0.140 \\
9((Cit, Cha), (Sil, Gym))) & -237758.976 & 16.395 & 0.140 \\
10(Cha, (Gym, (Cit, Sil))) & -237756.070 & 13.489 & 0.129 \\
11(Sil, (Cha, (Cit, Gym))) & -237760.049 & 17.468 & 0.069 \\
12(Sil, (Gym, (Cit, Cha))) & -237764.849 & 22.268 & 0.051 \\
13(Cit, (Sil, (Cha, Gym))) & -237761.012 & 18.431 & $0.030^{*}$ \\
14((Cha, Gym), (Cit, Sil)) & -237765.117 & 22.536 & $0.009^{*}$ \\
15(Sil, (Cit, (Cha, Gym))) & -237765.958 & 23.377 & $0.001^{*}$ \\
\hline
\end{tabular}

a Gym: Gymnotiformes; Cit: Citharinoidei; Cha: Characoidei; Sil: Siluriformes.

${ }^{\text {b }}$ Statistically significant differences $(\leq 0.05)$ denoted by asterisks.

Charachoidei, another suborder of Characiformes, basal relationships were poorly resolved and only four of the 19 internal branches that connect two species from the same families received the highest statistical support (100\% BSPs; Figure 3). With the exception of such ambiguous basal relationships, the resulting phylogenies showed several similarities to those reported by Calcagnotto et al. [20], who analyzed four nuclear and two mitochondrial genes across 124 characiform taxa. In

\begin{tabular}{|c|c|c|c|}
\hline Tree $^{a}$ & $\ln L$ & Diff $-\ln L$ & $P^{b}$ \\
\hline $1($ Gym, (Cit, (Cha, Sil))) & -131608.5 & best & 0.723 \\
\hline 2(Gym, (Cha, (Cit, Sill))) & -131610.3 & 1.758 & 0.447 \\
\hline 3(Gym, (Sil, (Cit, Cha))) & -131612.0 & 3.495 & 0.200 \\
\hline $4(($ Cit, Cha), (Sil, Gym)) & -131649.9 & 41.379 & $0.006^{*}$ \\
\hline 5(Cha, (Gym, (Cit, Sil))) & -131633.8 & 25.322 & $0.005^{*}$ \\
\hline 6(Cit, (Gym, (Cha, Sill))) & -131644.2 & 35.689 & $0.004^{*}$ \\
\hline $7(($ Cha, Gym), (Cit, Sil)) & -131633.6 & 25.100 & $0.003^{*}$ \\
\hline 8(Cha, (Sil, (Cit, Gym))) & -131657.8 & 49.233 & $0.002^{*}$ \\
\hline 9(Sil, (Gym, (Cit, Cha))) & -131656.9 & 43.761 & $0.001^{*}$ \\
\hline 10(Cha, (Cit, (Sil, Gym))) & -131656.9 & 45.503 & $0.001^{*}$ \\
\hline $11($ Cit, (Cha, (Sil, Gym))) & -131654.0 & 45.504 & $0.001^{*}$ \\
\hline 12(Sil, (Cit, (Cha, Gym))) & -131656.9 & 48.413 & $0.001^{*}$ \\
\hline 13(Cit, (Sil, (Cha, Gym))) & -131656.9 & 48.413 & $0.001^{*}$ \\
\hline 14((Cit, Gym), (Cha, Sil)) & -131644.2 & 35.662 & $0.000^{*}$ \\
\hline 15(Sil, (Cha, (Cit, Gym))) & -131657.9 & 49.336 & $0.000^{*}$ \\
\hline
\end{tabular}

a Gym: Gymnotiformes; Cit: Citharinoidei; Cha: Characoidei; Sil: Siluriformes.

${ }^{\mathrm{b}}$ Statistically significant differences $(\leq 0.05)$ denoted by asterisks. particular, we confirmed that the two African lineages represented by Hepsetidae (Hepsetus) and Alestidae (Phenacogrammus and Micralestes) did not form a monophyletic group, but were nested in the same clade with strictly Neotropical species, such as Hydrolycus (Cynodontidae) and Hoplias (Erythrinidae) (Figure 3).

In Siluriformes, monophyly of the two currently recognized suborders (Loricaroidei, Siluroidei [21]) was confirmed and the Loricaroidei was recovered as sister to other clades, followed by the divergence of Diplomystoidei and Siluroidei (BSP $=82 \%$; Figure 3 ). These basal divergences are fully congruent with the results of a recent molecular phylogenetic study by Sullivan et al. [21], who analyzed two nuclear genes across 110 catfish species representing 36 of 37 families. Thus, the two different lines of evidence support the most basal Loricaroidei in the siluriform phylogenies. Note that previous morphological studies have consistently argued the most basal Diplomystoidei ([41,84-89]), which was supported by a molecular study by Hardman [22], who used Diplomystes mesembrinus (Diplomystidae) as the only outgroup to root the tree. Within the Loricaroidei, a sister group relationship between Pterygoplichthys (Loricaridae) and Astroblepus (Astroblepidae) was strongly supported as in previous morphological and molecular studies $[21,89]$. As in the Characoidei, basal relationships in the Siluroidei were poorly resolved and only five of the 23 internal branches received high statistical support ( $\geq 95 \%$ BSPs; Figure 3). Nevertheless we recovered some of the suprafamilial clades reported by Sullivan et al. [21], and list them below with genera used in this study (Figure 3): "Big Asia" (Pseudobagrus, Hara, Liobagrus), "Claroidea (Cla)" (Clarias, Heteropneustes), "Aspredinidae + Doradoidea (Asp + Dor)" (Bunocephalus, Amblydoras, Tatia, Tetranematichthys), "Ictaluroidea (Ict)" (Ictalurus, Cranoglanis), and "Big Africa" (Synodontis, Amphilius, Malapterurus, Auchenoglanis, Chrysichthys, Pareutropius).

\section{Estimation of divergence time}

MCMCTREE analyses of the divergence times based on the two data sets $\left(12_{n} \mathrm{RT}_{\mathrm{n}}\right.$ and $\left.123_{\mathrm{a}}\right)$ with the assumption of independent rates (IR) across nodes yielded similar estimated node ages (see Additional file 1). Overall dating analysis based on the nucleotide data set $\left(12_{n} \mathrm{RT}_{\mathrm{n}}\right)$ provided slightly older node ages (absolute differences in posterior means: 16.3 million years \pm 21.5 SD) with consistently smaller 95\% credible intervals (absolute differences: 30.3 million years $\pm 23.0 \mathrm{SD}$ ) than those from the amino acid data set $\left(123_{\mathrm{a}}\right)$. Consequently the $95 \%$ credible intervals from both data sets greatly overlapped with each other across all nodes. These tendencies held true for the estimated node ages from the most recent common ancestors (MRCAs) of the five 
major otophysan lineages themselves (Cypriniformes, Gymnotiformes, Citharinoidei, Characoidei, Siluriformes) and those from MRCAs comprising subsets of these five lineages (total $=$ nine nodes), with the absolute difference in posterior means of 17.8 million years \pm 5.7 $\mathrm{SD}$. Considering the long evolutionary history of actinopterygians ( $\approx 450$ million years), the differences seem minor and the following description and discussion of the results were based on the nucleotide data set $\left(12_{n} \mathrm{RT}_{\mathrm{n}}\right)$ for simplicity.

MCMC analysis based on the $12{ }_{n} \mathrm{RT}_{\mathrm{n}}$ data set indicated that an ancestral lineage of the modern otophysans diverged from a stem ostariophysan during the end-Permian about $261 \mathrm{Ma}$ with a 95\% credible interval of 240-282 Ma (Figure 6). Basal otophysan divergences that produced common ancestors of the five modern lineages were estimated to occur in a relatively short time window during the Triassic (251-200 Ma): divergences between Cypriniformes and Characiphysi $=248$ Ma (with a 95\% credible interval of 227-268 Ma); Gymnotiformes and Characiformes + Siluriformes $=226 \mathrm{Ma}$ (206-245 Ma); Citharinoidei and Characoidei + Siluriformes $220 \mathrm{Ma}$ (201-240 Ma), Characoidei and Siluriformes $216 \mathrm{Ma}$ (198-237 Ma). The origins of these ancestral lineages were followed by the onset of radiations in each lineage during the Jurassic (200-146 Ma), with the estimated ages of the most recent common ancestor (MRCA) of the modern Cypriniformes $=160$ Ma (130-186 Ma); Gymnotiformes = $189 \mathrm{Ma}(166-212$ $\mathrm{Ma})$; Citharinoidei = $160 \mathrm{Ma}$ (124-190 Ma); Characoidei $=192(172-213 \mathrm{Ma})$; and Siluriformes $=180 \mathrm{Ma}(162-$ $198 \mathrm{Ma}$ ). For the summary of MCMC samples for node ages and entire timetree including non-otophysans, see Additional files 2 and 3, respectively.

We confirmed that uncertainties in relationships among major characiphysan lineages (Gymnotiformes, Citharinoidei, Characoidei, Siluriformes) least affect divergence time estimates, with the largest difference being only 10 million years (Table 7 ). In addition, despite the use of the IR model across nodes using MCMCTREE in the present study, the resulting ages for selected nodes were very similar to those reported in previous studies employing the AR model using MULTIDIVTIME [43,68] (Table 8). When the AR model was used in MCMCTREE (clock = 3), differences in the resulting node ages were minor, with absolute differences in posterior means of 0.7 million years \pm 16.4 SD (Additional file 1). Thus, the topological uncertainties and use of the different models of rate variations across nodes (and associated software) did not affect the divergence time estimates, at least in the present data set.

Our age estimates, however, are remarkably older than those indicated in previous reports based on the fossil record [43,68,90-92]. For example, the oldest otocephalan fossil discovered to date was from the Late Jurassic $150 \mathrm{Ma}$ [93], while our estimate was $265 \mathrm{Ma}$. The oldest otophysan fossil record dates back to the Albian (100-112 Ma) [94], while our estimate was 248 Ma. For all other major otophysan lineages, our molecular estimates (from $160 \mathrm{Ma}$ in Cypriniformes to $220 \mathrm{Ma}$ in Characiformes) are over 100 million years older than those of the fossil records used as minimum constraints (from $8 \mathrm{Ma}$ in Gymnotiformes to $98 \mathrm{Ma}$ in Characiformes; Table 4). Azuma et al. [43] also noted such large differences and plotted minimum time constraints based on the fossil record against molecular time estimates of the corresponding nodes. They found that four data points in the Paleozoic showed a fairly good 1:1 relationship, whereas other points in the Mesozoic were considerably below the line of a 1:1 relationship. They considered that these significant departures from the expected relationships for the Mesozoic fossils may reflect the fact that they do not really represent the oldest fossil for the corresponding lineages.

For such remarkably older molecular estimates, Benton and Ayala [51] noted four pervasive biases that may cause molecular dates to be too old: 1) the calibration dates that are too old based on previous molecular studies; 2) undetected rapidly evolving genes; 3 ) an ancestral polymorphism that was maintained through a long evolutionary period; and 4) asymmetric distributions of estimated times, with a constrained younger end but an unconstrained older end. As discussed by Azuma et al. [43], whose data set formed the basis of this study, the first factor is not the case in the present study because we did not use calibration dates based on previous molecular studies. The third factor would be applicable when the genomic regions used are under long-term balancing selection, but no mitochondrial genes have been reported to be under such selection. Neither the second factor nor the fourth factor are true in this study because quickly saturated third codon positions and the control region were excluded from the present analysis, and because each mitochondrial gene used here was tested and shown to perform well for dating vertebrate divergences [95]. We agree with the arguments of Azuma et al. [43] as well as those of Benton and Ayala [51], who stated that "careful choice of genes may be a more appropriate strategy (than the larger data strategy), with a focus on long and fast-evolving (yet alignable) sequences" for reliable dating. Whole mitogenome sequences seem to accommodate such requirements.

Recently Peng et al. [30] and Saitoh et al. [12] estimated divergence times of Ostariophysi and Cypriniformes, respectively, based on whole mitogenome sequences. As expected from similarities in the data sets and priors used in the relaxed-molecular clock Bayesian analysis, their estimates generally agreed with those of 


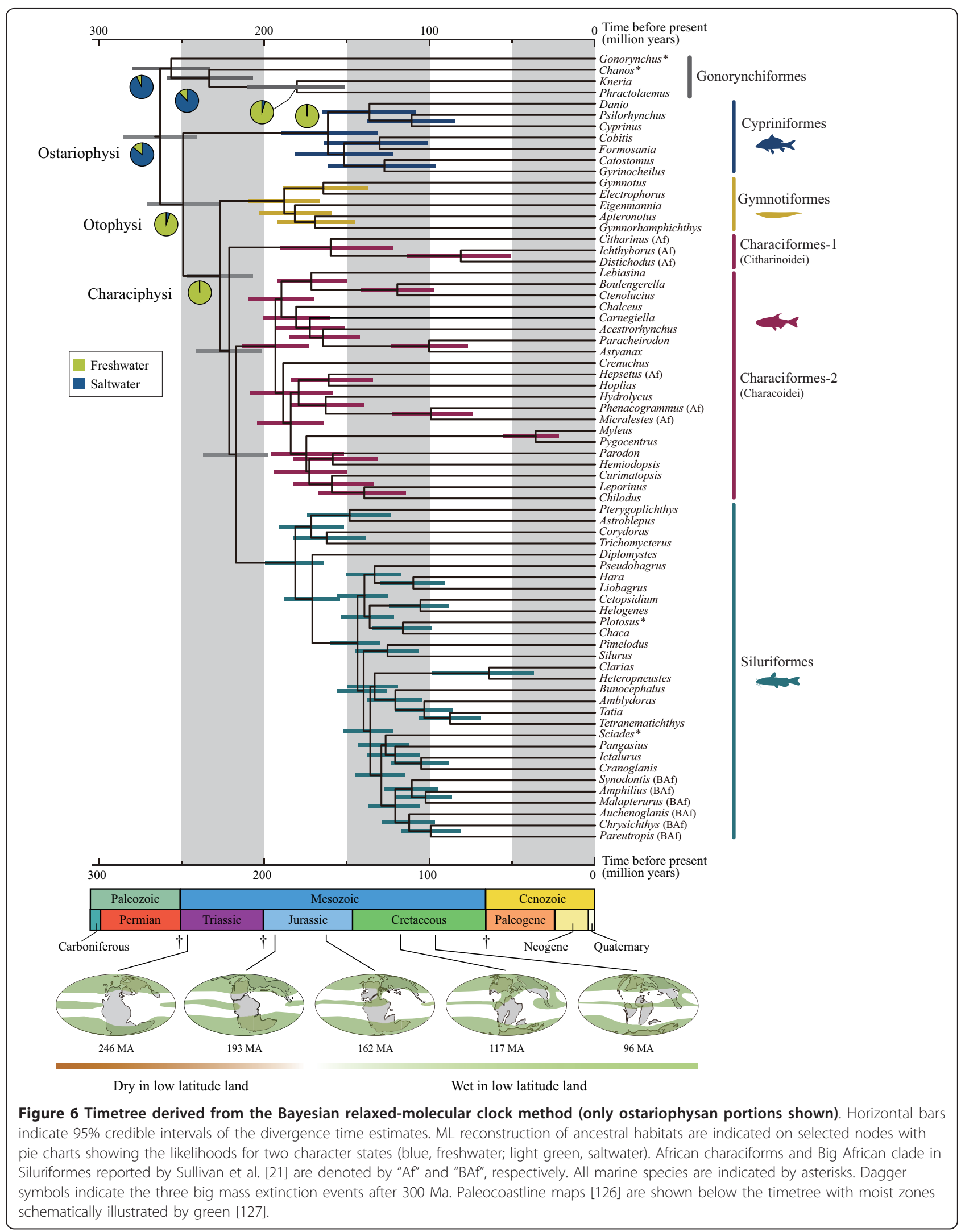


Table 7 Comparisons of the divergence time estimates $(\mathrm{Ma})$ for selected nodes from alternative tree topologies

\begin{tabular}{llllll}
\hline Node $(\text { MRCA })^{\mathbf{a}}$ & $\begin{array}{l}\text { Topology } \mathbf{1}(\boldsymbol{P}= \\
\mathbf{0 . 7 0 2})\end{array}$ & $\begin{array}{l}\text { Topology } \mathbf{2}(\boldsymbol{P}= \\
\mathbf{0 . 5 8 8})\end{array}$ & $\begin{array}{l}\text { Topology } \mathbf{1 4}(\boldsymbol{P}= \\
\mathbf{0 . 0 0 9})\end{array}$ & $\begin{array}{l}\text { Topology } \mathbf{1 5}(\boldsymbol{P}= \\
\mathbf{0 . 0 0 1})\end{array}$ & $\begin{array}{l}\text { Topology } \mathbf{9}(\boldsymbol{P}= \\
\mathbf{0 . 1 4 0})\end{array}$ \\
\hline Ostariophysi & $261(240-282)$ & $261(237-282)$ & $260(236-282)$ & $261(237-283)$ & $259(236-281)$ \\
Otophysi & $248(227-268)$ & $246(225-267)$ & $245(224-266)$ & $245(223-267)$ & $245(224-267)$ \\
Cypriniformes & $159(130-186)$ & $160(131-188)$ & $160(132-187)$ & $159(131-186)$ & $160(132-187)$ \\
Characiphysi & $226(206-245)$ & $224(203-244)$ & $220(200-239)$ & $220(201-242)$ & $220(200-242)$ \\
Gymnotiformes & $189(166-212)$ & $184(163-206)$ & $179(159-198)$ & $180(157-200)$ & $180(158-201)$ \\
Citharinoidei & $160(124-190)$ & $152(118-185)$ & $155(120-186)$ & $154(120-186)$ & $153(119-188)$ \\
Characoidei & $192(172-213)$ & $190(171-210)$ & $187(168-207)$ & $187(167-210)$ & $188(169-209)$ \\
Siluriformes & $180(162-198)$ & $180(162-197)$ & $179(161-197)$ & $180(162-197)$ & $180(162-197)$
\end{tabular}

Four topologies with the two best (topologies 1 and 2) and worst (topologies 14 and 15) probabilities of AU tests in Table 3 plus that of Fink \& Fink (topology 9 ) [27]. Upper and lower values are means and ranges of $95 \%$ posterior probabilities, respectively.

a Indicated by taxonomic names of the most recent common ancestor (MRCA)

our study (Table 9). More recently Santini et al. [96] analyzed divergence times for major fish lineages including those of Otophysi to investigate the effects of fishspecific whole-genome duplication events on the radiations of teleost fishes. Their analyses were based on the nuclear RAG1 gene sequences across 227 vertebrates downloaded from the database, and the phylogenetic relationships were reconstructed by constraining the monophyly of several groups to reflect generally accepted phylogenies. They used BEAST [64] to estimate divergence times under a model of uncorrelated but lognormally distributed rates, with soft upper (= maximum) bounds assigned to the prior distributions of 45 fossil calibrations using lognormal distributions. Note that their estimated ages are considerably younger than those in our study and those reported by Peng et al. [30] and Saitoh et al. [12] (Table 9) and thus require explanation.

As expected from the remarkably narrow $95 \%$ credible intervals in the estimated ages for Otocephala (149-153 Ma; Table 9), Santini et al. [96] set both minimum (149 $\mathrm{Ma})$ and maximum (152 Ma) time constraints for the MRCA of Ostarioclupeomorpha (= Otocephala in this study). The upper bound (152 Ma) was chosen based on their strong belief that the MRCA of Otocephala was unlikely to be older than the oldest stem elopomorph (true eels and their relatives: †Anaethalion) from the late Kimmeridgian, Jurassic 152 Ma [42]. Accordingly, they manipulated three priors of the lognormal distribution (offset $=149$; mean $=0.1 ; \mathrm{SD}=0.6$ ), which allowed only $5 \%$ of the MCMC samples to exceed the soft upper bound (152 Ma). This approach is called "phylogenetic bracketing" [97], which obtains not only minimum, but also maximum constraints on the timing of a branching event using the dates of the preceding and subsequent branching episodes [98,99]. Donoghue and Benton [97] argued that phylogenetic bracketing may be problematic because it assumes that the branching events above and below a calibration more reliably capture the timing of the branching event in question than the estimated date of the calibration itself. For other clades within the Otocephala, Santini et al. [96] also set relatively narrow time constraints: Ostariophysi (125-149 Ma), Characiformes (68-100 Ma), and Siluriformes (73-83.5 Ma). Accordingly, their resulting estimates (Table 9) fit very well with the fossil records and little chance exists $(<5 \%)$ that the MRCA of Otocephala is more than 152 Ma.

We recognize that the approach in Santini et al. [96] is superior in that it can lend more credence to the fossil record than the standard minimum-age constraints. Nevertheless, we did not provide upper (maximum) bounds for these nodes or manipulate two parameters of the truncated Cauchy distributions (= lognormal distributions in Santini et al. [96]) because insufficient information exists with which to specify meaningful prior distributions for most otophysan diversification

Table 8 Comparisons of divergence time estimates (Ma) for basal actinopterygian nodes between the present and previous mitogenomic studies

\begin{tabular}{lccc}
\hline Node (MRCA) & This study (Topology 1) & Setiamarga et al. [68] & Azuma et al. [43] \\
\hline Osteichthyes & $445(419-472)$ & $428(419-442)$ & $429(417-449)$ \\
Actinopterygii & $425(401-449)$ & $411(398-419)$ & $415(400-434)$ \\
Actinopteri & $380(360-395)$ & $383(368-392)$ & $384(370-392)$ \\
Neopterygii & $362(339-381)$ & $364(346-378)$ & $365(348-378)$ \\
Teleostei & $334(312-357)$ & $332(312-350)$ & $331(312-348)$ \\
Clupeocephala & $293(271-315)$ & $289(269-310)$ & $288(268-307)$ \\
\hline
\end{tabular}

\footnotetext{
a Indicated by taxonomic names of the most recent common ancestor (MRCA)
} 
Table 9 Comparisons of divergence time estimates (Ma) for basal actinopterygian nodes between the present and previous mitogenomic studies

\begin{tabular}{|c|c|c|c|c|}
\hline Node (MRCA) ${ }^{a}$ & This study (Topology 1) & Peng et al. [30] & Saitoh et al. [12] & Santini et al. [96] \\
\hline Otocephala & $265(243-286)$ & $279(264-293)$ & $251(230-273)$ & $151(149-153)$ \\
\hline Ostariophysi & $261(240-282)$ & - - - & $239(218-260)$ & $128(125-134)$ \\
\hline Anotophysi & $254(232-276)$ & $242(-—)$ & $228(206-250)$ & -—- \\
\hline Otophysi & $248(227-268)$ & $251(-—)$ & $220(198-241)$ & -—- \\
\hline Cypriniformes & $160(130-186)$ & $183(-—)$ & $156(136-176)$ & $92(56-123)$ \\
\hline Characiphysi & $226(206-245)$ & $210(-—)$ & $185(164-207)^{b}$ & - - - \\
\hline Gymnotiformes & $189(166-212)$ & $150(-—)$ & -—— & -—— \\
\hline Characiformes & $220(201-240)$ & $203(-—)$ & $160(139-183)^{b}$ & $80(68-84)$ \\
\hline Siluriformes & $180(162-198)$ & $173(-—)$ & $125(104-148)^{b}$ & $88(77-98)$ \\
\hline
\end{tabular}

${ }^{a}$ Indicated by taxonomic names of the most recent common ancestor (MRCA)

${ }^{\mathrm{b}}$ Including only two characoid characiforms plus two siluriforms, which are likely to provide underestimation of the node ages owing to insufficient taxonomic sampling.

times. Thus, the remarkable gaps between estimated ages from the two studies mostly reflect differences in priors on node ages (as the time constraints) rather than differences in software (MCMCTREE vs. BEAST) or data (mitogenomes vs. nuclear genes).

Some recent studies have argued that mitochondrial genes are likely to yield older node ages than nuclear genes. For example, Hurley et al. [100] investigated the relationships and divergence times of the basal actinopterygians (including teleosts) using four nuclear genes and whole mitogenomes. A relaxed molecular clock Bayesian analysis based on these two data sets provided node ages for the most recent common ancestor of teleosts with posterior means of $219 \mathrm{Ma}$ (181-265 Ma) and 246 Ma (206-292 Ma) depending orthologues in the nuclear genes (only the former estimate shown in their figure 4) and $296 \mathrm{Ma}$ (268-326 Ma) in the mitochondrial genome (data taken from their supplementary tables 3 and 7). Despite the overlap between these two results (95\% credible intervals), Hurley et al. [100] concluded that the mitochondrial estimate of the most recent common ancestor of teleosts was 50-100 million years older than that of the nuclear genes. Based on this comparison, they further argued that the discrepancy between their nuclear and mitochondrial estimates may have been due to evolutionary rate differences between these two genomes. Note that their nuclear estimation did not include any species from the osteoglossomorphs (the putative most primitive teleosts; see Figure 3), which is likely to result in underestimation of the crown node age of teleosts with insufficient taxon sampling.

More recently, Brandley et al. [52] investigated intercontinental dispersal of Plestiodon (Eumeces) lizards based on analysis of a single mitochondrial gene (ND1) plus seven nuclear genes. They performed a relaxed molecular clock Bayesian divergence time estimation using unpartitioned and partitioned data sets across these genes and found that extreme saturation obscured the underlying rate of evolution in the mitochondrial gene, resulting in overestimation of the divergence times. Such overestimation in the mitochondrial gene was most pronounced in the unpartitioned data set and less so in the two partitioned data sets. Brandley et al. [52] agreed with Phillips [101], who demonstrated that genes or gene partitions that evolve at extremely high rates may accumulate so many hidden substitutions, making it difficult to estimate the underlying process that created the data. Although their arguments are convincing, comparisons made by Brandley et al. [52] were based on a single mitochondrial gene, including third codon positions. We used whole mitochondrial genomes with various substitution rates across genes [102], excluded quickly saturated third codon positions entirely, and partitioned the data sets.

Also the estimated ages may be too old simply because of the entire absence of a fossil record [100]. The absence of fossils, however, should not be taken as evidence of absence, as discussed extensively by Diogo [41]. In an article on the early radiation of teleosts, Arratia [42] stated “... we know almost nothing concerning the fossil record of most otophysans, of most living perciforms, atheriniforms, etc." Thus, to assume a lack of otophysan fossil record during the Mesozoic is natural if the group existed as stem groups during this period.

As Brown et al. [72] convincingly argued, although ample room for improvement exists on both sides of the "rock-clock" divide (e.g., accounting for ghost lineages in the fossil record and developing more realistic models of rate evolution for molecular genetic sequences), the consistent and conspicuous disagreement between these two sources of data more likely reflects a genuine difference between estimated ages of 1) stem group origins and 2) crown group morphological diversification, respectively. 


\section{Comments on trans-Atlantic clades}

Although this study was not intended to address questions regarding historical biogeography of the otophysans, divergence times of some of the transcontinental sister group relationships, particularly those between Africa and South America in Characiformes and Siluriformes, warrant brief comments regarding their origins.

Based on a hypothesis presented by Backup (unpublished thesis [103]), Lundberg [37] examined the implications of applying a strict vicariance scenario to the three transcontinental sister group pairs in Characiformes and noted that most of the diversification among characiforms would have occurred prior to the continental breakup (i.e., on Gondwana). Our timetree corroborates this hypothesis because all of our divergence time estimates of the three transcontinental pairs (Citharinoidei vs. Characoidei $=220 \mathrm{Ma}$; two alestids Micralestes + Phenacogrammus vs. Hydrolycus $=162$ Ma; Hepsetus vs. Hoplias $=160 \mathrm{Ma}$ ) fall well before the Gondwanan separation (100-120 Ma) [104]. Note, however, that recent discoveries of marine or brackish characiforms (Santanichthys [94] and Sorbinicharax [105]) from the Cretaceous challenge such a simple vicariance hypothesis [106].

Recently Lundberg et al. [107] examined the relationships of a highly distinct freshwater catfish, Lacantunia enigmatica (Lacantuniidae) from Chipas, Mexico, and found that Lacantunia was derived from within a multifamily clade of African freshwater catfishes ("Big Africa" in Sullivan et al. [21]; see Figures 3, 6). Based on a maximum-age constraint of $144 \mathrm{Ma}$ for the stem of the siluriform lineage (= siluriform + gymnotiform node) and seven additional minimum-age constraints for the internal nodes, they estimated the divergence time of Lacantunia using a relaxed-molecular clock method implemented in MULTIDIVTIME [69] and r8s [108]. The resulting divergence estimates ranged from 83 to $87 \mathrm{Ma}$ depending on the partitioning schemes with $95 \%$ credible intervals of 75-94 Ma. These ages fall after the separation of Africa and South America, and Lundberg et al. [107] proposed a new scenario based on an ancient intercontinental passage for explaining disjunct distributions of relictually endemic Lacantunia and its African sister clade. Also note that they acknowledge that their choice of $144 \mathrm{Ma}$ as the maximum-age constraint is arbitrary, but conservatively informed by the fossil record of actinopterygians. Although we did not include Lacantunia in our analyses, the onset of diversification of the Big African clade is estimated to be $129 \mathrm{Ma}(113-144 \mathrm{Ma})$ and divergence of Lacantunia from its stem should be much older. Thus our estimated ages did not require an ancient intercontinental passage as hypothesized by Lundberg et al. [107].

\section{History of diversification}

ML reconstruction of the ancestral habitats on the timetree suggests that a shift from character state 0 (saltwater) to 1 (freshwater) occurred between the crown node of Ostariophysi $\left(P_{0}=0.859 ; P_{1}=0.142\right)$ and that of Otophysi $\left(P_{0}=0.055 ; P_{1}=0.945\right)$, corresponding to the end-Permian (263-249 Ma) (Figure 6). Moreover, a similar habitat shift was also recovered in Gonorynchiformes, a sister clade of Otophysi (Figure 6). Based on these ancestral habitat reconstructions and the divergence time estimates with reference to Earth's history, we identified the following five global turning points in the history of otophysan diversification. Note, however, that the true ancestral habitats and dynamics of diversification cannot be inferred from time-calibrated phylogenies of the extant lineages alone [109]; one need to include the fossil record to fully understand the ancestral habitats and diversity dynamics of the otophysans.

First, the common ancestor of Otophysi presumably entered freshwater around 263-249 Ma. This period corresponds to the end-Permian when the largest mass extinction in Earth's history occurred, wiping out $96 \%$ of all species [110]. The end-Permian mass extinction has been associated with a massive release of carbon gases into the atmosphere, causing a global greenhouse effect and abrupt climate warming [111]. During the same time, the oceans are believed to have become anoxic worldwide [112,113] and to have contained free hydrogen sulfide [114]. These environmental perturbations greatly altered the marine ecosystems [115] and may have driven fish extinctions. Note that freshwater contains much higher levels of dissolved oxygen than saltwater for a given atmospheric concentration, and this difference can affect the biology of the organisms [116]. The possible habitat shift (from salt- to freshwater) in the common ancestor of Otophysi should have a causal relationship with the survival of this lineage across the end-Permian. To our knowledge, however, no comparable examples of habitat shift in other groups of organisms exist that independently support this evolutionary scenario.

Second, the five major otophysan lineages (corresponding to common ancestors of the presentday orders or suborders) have successively originated from an ancestral lineage of the otophysans in a short time window during the Triassic (251-200 Ma). During this period all continents remained united as the supercontinent Pangaea, with a climate characterized by globally warm temperatures, extreme seasonality, and high aridity over much of the inland region [117]. However, the climate was more moderate around the edges of the supercontinent. The regions around Pangaea had sufficient rainfall to produce 
vigorous forests along riverbanks [118], which possibly facilitated stepwise divergences of the five lineages on Pangaea. Note that the Pangaea was cut almost in half along the east-west axis by a huge embayment called the Tethys Seaway (Figure 6). Over time, as the Tethys Seaway expanded, it may have led to the first vicariant divergence between the common ancestors of Cypriniformes and Characiphysi as suggested by Saitoh et al. $[4,12]$.

Third, these five major otophysan lineages survived the end-Triassic mass extinction, which was one of the five largest extinctions in Earth's history in which 80\% of all species became extinct [117]. Widespread magmatic activity of the Central Atlantic Magmatic Province (CAMP) has been suggested to have caused this catastrophic event, and repeated release of $\mathrm{SO}_{2}$ gas, heavy metal emissions, and darkening were the main environmental stressors [119]. Relatively long stem branches from the common ancestors of the five major lineages across the Triassic-Jurassic boundary suggest profound effects of the mass extinction and associated environmental perturbations on the patterns of otophysan diversification.

Fourth, extant otophysan lineages began to diversify in each of the five clades during the Jurassic and through the early Cretaceous (200-100 Ma) (Figure 6), providing a framework for the modern otophysan diversity. The onset of diversification depends on the clade (193-160 Ma), although all fell in the Jurassic (200-146 Ma). Note that familial diversification of the South American gymnotiforms, characoids, and loricaroids was recovered much earlier than that of cypriniforms, citharinoids and siluroids (Figure 6). The Jurassic was a time of particularly swift change due to the Pangaean breakup and the resulting development of new oceans and a gentle tropical climate over the formerly arid interiors of the supercontinent [118]. Such environmental changes likely yielded numerous novel habitats, facilitating otophysan diversification throughout the Mesozoic until about $100 \mathrm{Ma}$.

Finally these modern otophysan lineages established during the Mesozoic survived the third mass extinction event at the end of the Cretaceous (Figure 6). Such "mass survival" of the modern lineages across the Cretaceous-Paleogene boundary has been noted for birds and mammals based on molecular evidence [120].

The present timetree suggests a Pangaean origin and Mesozoic radiations of the modern otophysans. This evolutionary scenario is in good agreement with recent biogeographic inferences. For example Diogo [41] broadly surveyed the higher-level phylogeny, biogeographic distribution, physiology, and ecology of catfishes, and suggested that these fishes originated at a time when some Pangaean connections still existed between Laurasia and Gondwana. In addition, Briggs [33] examined the phylogeny and geographic distribution patterns of ostariophysan fishes and proposed the Late Jurassic (160-150 Ma) origins of the cypriniforms and siluriforms, which are highly congruent with the estimated node ages for the most recent common ancestor of Cypriniformes (160 Ma) and Siluriformes (180 Ma) in this study.

Of course the evolutionary scenario presented here just represents a testable hypothesis and should be viewed with caution because the fossil record provides no direct evidence. Although Mesozoic freshwater deposits are geographically and stratigraphically patchy and the freshwater fishes from most of these deposits have not been fully documented across all continents [121-123], available information suggests that major components of the freshwater fishes were basal actinopterygians (non-teleost ray-finned fishes), chondrichthyans (sharks, rays, chimaeras) and sarcopterygians (lungfishes and coelacanths) [121-124], and few freshwater teleosts (e.g., the Late Triassic Jiangilichthys) are referable to extinct "pholidophoriforms," phylogenetically located outside the modern teleosts [125]. Moreover the fossil record suggests that the modern teleostean lineages did not diversify until the Late Jurassic about $150 \mathrm{Ma}$ [125]. Thus, acceptance of the present evolutionary scenario requires the origin and survival of the ghost lineage from the Triassic through Late Jurassic for over 100 million years.

\section{Conclusions}

The timetree presented here indicates that survival of the ancestral lineages through the two consecutive mass extinctions on Pangaea and subsequent radiations during the Jurassic and through the early Cretaceous shaped the modern familial diversity of otophysans. The Pangaean origin and Mesozoic radiations of the modern otophysans are consistent with recent arguments based on biogeographic inferences $[40,41]$ and molecular divergence time estimates $[37,40]$. No fossil otophysan, however, has been recorded before the Albian, the early Cretaceous 100-112 Ma [42], creating an over 100 million year time span without fossil evidence. This extremely large ghost range partially reflects a genuine difference between the estimated ages of stem group origin (molecular divergence time) and crown group morphological diversification (fossil divergence time) [72]; the ghost range, however, may be filled with future discoveries of older fossils that can be used as more reasonable time constraints as well as with the development of more realistic models that accurately capture the divergence rates of molecular sequences. 


\section{Additional material}

\section{Additional file 1: A cladogram showing all nodes with $<50 \%$ BSPs} in Figure 3 collapsed to polytomy.

Additional file 2: Summary of MCMC samples for node ages (means and $95 \%$ credible intervals) in the independent-rates (IR) and autocorrelated-rates (AR) analyses using MCMCTREE-HS [63]. Results from the two data sets $\left(12_{n} R T_{n}\right.$ and $\left.123_{a}\right)$ are shown separately. For node numbers, see tree at the end of this file.

Additional file 3: Timetree derived from the Bayesian relaxedmolecular clock method (non-ostariophysan portions also shown)

Upper (maximum) and lower (minimum) time constraints used in this study are shown by arrowheads with corresponding nodes connected by dotted lines. All marine species are indicated by asterisks.

\section{Acknowledgements}

We sincerely thank J.G. Inoue, S. Kanao, S. Lavoué, R.M.S. Vega for providing materials, C. Oliveira for species' identification, Z. Yang for technical advice on MCMCTREE, and M. MacCampbell for reviewing an earlier version of the manuscript. G. Arratia kindly reviewed a portion of the revised manuscript, provided a large amount of information on the Mesozoic fishes, and pointed out inherent problems of our inferences from a paleontological view. Of course, the review does not imply her acceptance of our hypothesis on the otophysan diversification and any mistakes in logic or fact remain our responsibility. Our manuscript was improved following constructive and insightful comments from the three anonymous reviewers and the associate editor. Funding was provided by JSPS Research grants (17207007, 19207007, and 22370035).

\section{Author details}

'Atmosphere and Ocean Research Institute, The University of Tokyo, 5-1-5 Kashiwanoha, Kashiwa-shi, Chiba 277-8564, Japan. ${ }^{2}$ Natural History Museum and Institute, Chiba, 955-2 Aoba-cho, Chuo-ku, Chiba 260-8682, Japan. ${ }^{3}$ National Research Institute of Fisheries Science, 2-12-4 Fukuura, Kanazawa, Kanagawa 236-8648, Japan.

\section{Authors' contributions}

$\mathrm{MNa}, \mathrm{MM}, \mathrm{KM}$ and $\mathrm{MNi}$ designed this study. MNa and KS mainly collected the specimens and carried out the molecular work. MNa and MM analyzed the data. MM drafted the original manuscript and $\mathrm{MNa}$, KM, KS and MNi contributed to its improvement. All authors read and approved the final manuscript.

Received: 29 January 2011 Accepted: 22 June 2011

Published: 22 June 2011

\section{References}

1. Dudgeon D, Arthington AH, Gessner MO, Kawabata ZI, Knowler DJ, Lévéque C, Naiman RJ, Prieur-Richard AH, Soto D, Stiassny ML: Freshwater biodiversity: importance, threats, status and conservation challenges. Biol Rev 2005, 81(02):163-182.

2. Schindler DE: Fish extinctions and ecosystem functioning in tropical ecosystems. Proc Natl Acad Sci USA 2007, 104(14):5707-5708.

3. Nelson JS: Fishes of the world. Hoboken, NJ: John Wiley \& Sons; 42006.

4. Saitoh K, Miya M, Inoue JG, Ishiguro NB, Nishida M: Mitochondrial genomics of ostariophysan fishes: Perspectives on phylogeny and biogeography. J Mol Evol 2003, 56(4):464-472.

5. Poulsen JY, Møller PDR, Lavoué S, Knudsen SW, Nishida M, Miya M: Higher and lower-level relationships of the deep-sea fish order Alepocephaliformes (Teleostei: Otocephala) inferred from whole mitogenome sequences. Biol J Linn Soc 2009, 98(4):923-936.

6. Lavoué S, Miya M, Inoue JG, Saitoh K, Ishiguro NB, Nishida M: Molecular systematics of the gonorynchiform fishes (Teleostei) based on whole mitogenome sequences: Implications for higher-level relationships within the Otocephala. Mol Phylogenet Evol 2005, 37(1):165-177.

7. Lavoué S, Miya M, Poulsen JY, Møller PR, Nishida M: Monophyly, phylogenetic position and inter-familial relationships of the
Alepocephaliformes (Teleostei) based on whole mitogenome sequences. Mol Phylogenet Evol 2008, 47(3):1111-1121.

8. Lecointre G: Gonorynchiformes in the teleostean phylogeny: molecules and morphology used to investigate interrelationships of the Ostariophysi. In Gonorynchiformes and ostariophysan relationships: a comprehensive review. Edited by: Grande T, Poyato-Ariza FJ, Diogo R. Enfield, NH: Science Publishers; 2010:

9. Miya M, Satoh TP, Nishida M: The phylogenetic position of toadfishes (order Batrachoidiformes) in the higher ray-finned fish as inferred from partitioned Bayesian analysis of 102 whole mitochondrial genome sequences. Biol J Linn Soc 2005, 85(3):289-306.

10. Miya M, Takeshima H, Endo H, Ishiguro NB, Inoue JG, Mukai T, Satoh TP, Yamaguchi M, Kawaguchi A, Mabuchi K, et al: Major patterns of higher teleostean phylogenies: a new perspective based on 100 complete mitochondrial DNA sequences. Mol Phylogenet Evol 2003, 26(1):121-138.

11. Saitoh K, Sado T, Mayden RL, Hanzawa N, Nakamura K, Nishida M, Miya M: Mitogenomic evolution and interrelationships of the Cypriniformes (Actinopterygii: Ostariophysi): The first evidence toward resolution of higher-level relationships of the World's largest freshwater fish clade based on 59 whole mitogenome sequences. J Mol Evol 2006, 63(6):826-841

12. Saitoh K, Sado T, Doosey MH, Bart HL, Inoue JG, Nishida M, Mayden RL, Nishida M, Miya M: Evidence from mitochondrial genomics supports the lower Mesozoic of South Asia as the time and place of basal divergence of cypriniform fishes (Actinopterygii: Ostariophysi). Zool J Linn Soc 2011, 161:633-662

13. Mayden RL, Tang KL, Wood RM, Chen W-J, Agnew MK, Conway KW, Yang L, Simons AM, Bart HL, Harris PM, et al: Inferring the Tree of Life of the order Cypriniformes, the earth's most diverse clade of freshwater fishes: implications of varied taxon and character sampling. J Systemat Evol 2008, 46(3):424-438.

14. Chen WJ, Miya M, Saitoh K, Mayden RL: Phylogenetic utility of two existing and four novel nuclear gene loci in reconstructing Tree of Life of ray-finned fishes: The order Cypriniformes (Ostariophysi) as a case study. Gene 2008, 423(2):125-134.

15. He S, Gu X, Mayden RL, Chen W-J, Conway KW, Chen Y: Phylogenetic position of the enigmatic genus Psilorhynchus (Ostariophysi: Cypriniformes): Evidence from the mitochondrial genome. Mol Phylogenet Evol 2008, 47(1):419-425

16. Mayden RL, Chen WJ, Bart HL, Doosey MH, Simons AM, Tang KL, Wood RM, Agnew MK, Yang L, Hirt MV, et al: Reconstructing the phylogenetic relationships of the earth's most diverse clade of freshwater fishes -order Cypriniformes (Actinopterygii: Ostariophysi): A case study using multiple nuclear loci and the mitochondrial genome. Mol Phylogenet Evol 2009, 51(3):500-514.

17. Mayden RL, Chen WJ: The world's smallest vertebrate species of the Genus Paedocypris: A new family of freshwater fishes and the sister group to the world's most diverse clade of freshwater fishes (Teleostei: Cypriniformes). Mol Phylogenet Evol 2010, 57(1):152-175.

18. Chen W-J, Mayden RL: Molecular systematics of the Cyprinoidea (Teleostei: Cypriniformes), the World's largest clade of freshwater fishes: further evidence from six nuclear genes. Mol Phylogenet Evol 2009, 52:544-549.

19. Orti G, Meyer A: The radiation of characiform fishes and the limits of resolution of mitochondrial ribosomal DNA sequences. Syst Biol 1997, 46(1):75-100.

20. Calcagnotto D, Schaefer SA, Desalle R: Relationships among characiform fishes inferred from analysis of nuclear and mitochondrial gene sequences. Mol Phylogenet Evol 2005, 36(1):135-153.

21. Sullivan J, Lundberg J, Hardman M: A phylogenetic analysis of the major groups of catfishes (Teleostei: Siluriformes) using rag1 and rag2 nuclear gene sequences. Mol Phylogenet Evol 2006, 41(3):636-662.

22. Hardman M: The phylogenetic relationships among non-diplomystid catfishes as inferred from mitochondrial cytochrome b sequences; the search for the ictalurid sister taxon (Otophysi: Siluriformes). Mol Phylogenet Evol 2005, 37(3):700-720.

23. Alves-Gomes JA, Orti G, Haygood M, Heiligenberg W, Meyer A: Phylogenetic analysis of the South American electric fishes (order Gymnotiformes) and the evolution of their electrogenic system: a synthesis based on morphology, electrophysiology, and mitochondrial sequence data. Mol Biol Evol 1995, 12:298-318. 
24. Alves-Gomes JA: The mitochondrial phylogeny of the South American electric fish (Gymnotiformes) and an alternative hypothesis for the otophysan historical biogeography. In Gonorynchiformes and ostriophysan relationships: A comprehensive review. Edited by: Grande T, Poyato-Ariza FJ, Diogo R. Enfield, NH: Science Publishers; 2010:517-565.

25. Hennig W: Phylogenetic systematics. Urbana, IL: University of Illinois Press; 1996.

26. Wiley EO: Phylogenetics: the theory and practice of phylogenetic systematics. New York: Wiley \& Sons; 1981.

27. Fink SV, Fink WL: Interrelationships of the ostariophysan fishes (Teleostei). Zool J Linn Soc 1981, 72(4):297-353.

28. Dimmick WW, Larson A: A molecular and morphological perspective on the phylogenetic relationships of the otophysan fishes. Mol Phylogenet Evol 1996, 6(1):120-133.

29. Orti $G$, Meyer A: Molecular evolution of ependymin and the phylogenetic resolution of early divergences among euteleost fishes. Mol Biol Evol 1996, 13(4):556-573.

30. Peng Z, He S, Wang J, Wang W, Diogo R: Mitochondrial molecular clocks and the origin of the major otocephalan clades (Pisces: Teleostei): a new insight. Gene 2006, 370:113-124.

31. Li C, Lu G, Orti G: Optimal data partitioning and a test case for ray-finned fishes (Actinopterygii) based on ten nuclear loci. Syst Biol 2008, 57(4):519-539.

32. Novacek MJ, Marshall LG: Early biogeographic history of ostariophysan fishes. Copeia 1976, 1976(1):1-12.

33. Briggs JC: The biogeography of otophysan fishes (Ostariophysi: Otophysi): a new appraisal. J Biogeogr 2005, 32(2):287-294.

34. Briggs JC: Ostariophysan zoogeography: an alternative hypothesis. Copeia 1979, 1979:111-118.

35. Gayet M: Consideration sur la phylogenie et la paleobiographie des Ostariophysaries. Geobios 1982, 6:39-52

36. Banarescu P: Zoogeography of fresh waters. Wiesbaden, Germany: AULA Verlag; 19901.

37. Lundberg JG: African-South American freshwater clades and continental drift: problems with a paradigm. In Biological relationships between Africa and South America. Edited by: Goldblatt P. New Haven: Yale University Press; 1993:156-199.

38. Fara E, Gayet M, Taverne L: The Fossil record of Gonorynchiformes. In Gonorynchiformes and ostariophysan relationships: A comprehensive review. Edited by: Grande T, Poyato-Ariza FJ, Diogo R. Enfield, NH: Science Publishers; 2010:173-226.

39. Malabarba MC, Malabarba LR: Biogeography of Characiformes: an evaluation of the available information of fossil and extant taxa. In Origin and Phylogenetic Interrelationships of Teleosts. Edited by: Nelson JS, Schultze H-P. Wilson MVH. München: Verlag Dr. Friedrich Pfeil; 2010:

40. Conway KW, Hirt MV, Yang L, Mayden RL, Simons AM: Cypriniformes: systematics and paleontology. In Origin and phylogenetic interrelationships of teleosts. Edited by: Nelson JS, Schultze H-P, Wilson MVH. München: Verlag Dr. Friedrich Pfeil; 2010:

41. Diogo R: Phylogeny, origin and biogeography of catfishes: support for a Pangean origin of 'modern teleosts' and reexamination of some Mesozoic Pangean connections between the Gondwanan and Laurasian supercontinents. Anim Biol 2004, 54(4):331-351.

42. Arratia G: Mesozoic halecostomes and the early radiation of teleosts. In Mesozoic fishes 3. Edited by: Arratia G, Tintori A. München, Germany: Verlag Dr. Friedrich Pfeil; 2004:279-315.

43. Azuma Y, Kumazawa Y, Miya M, Mabuchi K, Nishida M: Mitogenomic evaluation of the historical biogeography of cichlids toward reliable dating of teleostean divergences. BMC Evol Biol 2008, 8(1):215.

44. Asahida T, Kobayashi T, Saitoh K, Nakayama I: Tissue preservation and total DNA extraction from fish stored at ambient temperature using buffers containing high concentration of urea. Fish Sci 1996, 62:727-730.

45. Miya M, Nishida M: Organization of the mitochondrial genome of a deep-sea fish, Gonostoma gracile (Teleostei: Stomiiformes): first example of transfer RNA gene rearrangements in bony fishes. Mar Biotechnol 1999, 1(5):416-426.

46. Cheng S, Chang SY, Gravitt P, Respess R: Long PCR. Nature 1994, 369(6482):684-645.

47. Katoh $\mathrm{K}$, Toh $\mathrm{H}$ : Recent developments in the MAFFT multiple sequence alignment program. Brief Bioinformatics 2008, 9(4):286-298.
48. Maddison WP, Maddison DR: MacClade Version 3. Sunderland: Sinauer Associates; 2000

49. Miya M, Nishida M: Use of mitogenomic information in teleostean molecular phylogenetics: a tree-based exploration under the maximumparsimony optimality criterion. Mol Phylogenet Evol 2000, 17(3):437-455.

50. Broughton RE: Phylogeny of teleosts based on mitochondrial genome sequences. In Origin and phylogenetic interrelationships of teleosts. Edited by: Nelson JS, Shultze H-S, Wilson MVH. München, Germany: Verlag Dr. Friedrich Pfeil; 2010:61-76.

51. Benton MJ, Ayala FJ: Dating the Tree of Life. Science 2003, 300(5626):1698-1700.

52. Brandley MC, Wang Y, Guo X, de Oca ANM, Fería-Ortíz M, Hikida T, Ota H: Accommodating high rates of evolution in molecular dating methods: an example using inter-continental dispersal of Plestiodon (Eumeces) lizards. Syst Biol 2011, 60(1):3-15.

53. Stamatakis A: RAxML-VI-HPC: maximum likelihood-based phylogenetic analyses with thousands of taxa and mixed models. Bioinformatics 2006 22(21):2688-2690

54. Yang Z: Estimating the pattern of nucleotide substitution. J Mol Evol 1994, 39(1):105-111.

55. Posada D, Crandall KA: MODELTEST: testing the model of DNA substitution. Bioinformatics 1998, 14(9):817-818.

56. Adachi J, Hasegawa M: Model of amino acid substitution in proteins encoded by mitochondrial DNA. J Mol Evol 1996, 42(4):459-468.

57. Shimodaira $\mathrm{H}$, Hasegawa M: CONSEL: for assessing the confidence of phylogenetic tree selection. Bioinformatics 2001, 17(12):1246-1247.

58. Shimodaira $\mathrm{H}$ : An approximately unbiased test of phylogenetic tree selection. Syst Biol 2002, 51(3):492-508.

59. Felsenstein J: Confidence limits on phylogenies: an approach using the bootstrap. Evolution 1985, 39(4):783-791

60. Kishino $\mathrm{H}$, Hasegawa M: Evaluation of the maximum likelihood estimate of the evolutionary tree topologies from DNA sequence data, and the branching order in hominoidea. J Mol Evol 1989, 29(2):170-179.

61. Shimodaira H, Hasegawa M: Multiple comparisons of log-likelihoods with applications to phylogenetic inference. Mol Biol Evol 1999, 16:1114-1116.

62. Kawahara R, Miya M, Mabuchi K, Near T, Nishida M: Stickleback phylogenies resolved: Evidence from mitochondrial genomes and 11 nuclear genes. Mol Phylogenet Evol 2009, 50(1):401-404.

63. Yang Z: PAML 4: phylogenetic analysis by maximum likelihood. Mol Biol Evol 2007, 24(8):1586-1591

64. Drummond AJ, Rambaut A: BEAST: Bayesian evolutionary analysis by sampling trees. BMC Evol Biol 2007, 7:214

65. Rannala B, Yang Z: Inferring speciation times under an episodic molecular clock. Syst Biol 2007, 56(3):453-466.

66. Zhong B, Yonezawa T, Zhong Y, Hasegawa M: Episodic evolution and adaptation of chloroplast genomes in ancestral grasses. PLOS ONE 2009, 4(4):e5297.

67. Yang Z, Rannala B: Bayesian phylogenetic inference using DNA sequences: a Markov chain Monte Carlo method. Mol Biol Evol 1997, 14(7):717-724.

68. Setiamarga DHE, Miya M, Inoue JG, Ishiguro NB, Mabuchi K, Nishida M: Divergence time of the two regional medaka populations in Japan as a new time scale for comparative genomics of vertebrates. Biol Lett 2009, 5(5):81-86

69. Thorne JL, Kishino H: Divergence time and evolutionary rate estimation with multilocus data. Syst Biol 2002, 51(5):689-702

70. Benton MJ, Donoghue PCJ: Paleontological evidence to date the Tree of Life. Mol Biol Evol 2006, 24(1):26-53.

71. Yang Z, Rannala B: Bayesian estimation of species divergence times under a molecular clock using multiple fossil calibrations with soft bounds. Mol Biol Evol 2006, 23(1):212-226.

72. Brown JW, Rest JS, García-Moreno J, Sorenson MD, Mindell DP: Strong mitochondrial DNA support for a Cretaceous origin of modern avian lineages. BMC Biol 2008, 6:6.

73. Mesquite: a modular system for evolutionary analysis Ver. 2.73. [http:// mesquiteproject.org].

74. Page M: The maximum likelihood approach to reconstructing ancestral character states of discrete characters on phylogenies. Syst Biol 1999, 48(3):612-622.

75. Schluter D, Price T, Mooers A, Ludwig D: Likelihood of ancestor states in adaptive radiation. Evolution 1997, 51(6):1699-1711. 
76. Lewis PO: A likelihood approach to estimating phylogeny from discrete morphological character data. Syst Biol 2001, 50(6):913-925.

77. Lartillot N, Philippe $\mathrm{H}$ : A Bayesian mixture model for across-site heterogeneities in the amino-acid replacement process. Mol Biol Evol 2004, 21(6):1095-1109.

78. Lartillot N, Lepage T, Blanquart S: PhyloBayes 3: a Bayesian software package for phylogenetic reconstruction and molecular dating. Bioinformatics 2009, 25(17):2286-2288

79. Buckup PA: Relationships of the Characidiinae and phylogeny of characiform fishes (Teleostei: Ostariophysi). In Phylogeny and classification of neotropical fishes. Edited by: Malabarba LR, Reis RE, Vari RP, Lucena ZMS, Lucena CAS. Porto Alegre, Brasil: Edipucrs; 1998:123-144.

80. Fink SV, Fink WL: Interrelationships of ostariophysan fishes (Teleostei). In Interrelationships of fishes. Edited by: Stiassny MLJ, Parenti LR, Johnson GD. San Diego: Academic Press; 1996:209-249.

81. Dahdul WM: Review of the phylogenetic relationships and fossil record of Characiformes. In Gonorynchiformes and ostriophysan relationships: A comprehensive review. Edited by: Grande T, Poyato-Ariza FJ, Diogo R. Enfield, New Hampshire: Science Publishers; 2010:441-464.

82. Vari RP: Anatomy, relationships and classification of the families Citharinidae and Distichodontidae (Pisces, Characoidea). Bull Brit Mus (Nat Hist) Zool Ser 1979, 36:261-344.

83. Ortí $G$, Petry P, Porto JIR, Jégu M, Meyer A: Patterns of nucleotide change in mitochondrial ribosomal RNA genes and the phylogeny of piranhas. $J$ Mol Evol 1996, 42(2):169-182

84. Grande L: Redescription of Hypsidoris farsonensis (Teleostei: Siluriformes), with a reassessment of its phylogenetic relationships. J Vert Paleontol 1987, 7:24-54.

85. Mo T: Anatomy, relationships and systematics of the Bagridae (Teleostei: Siluroidei) with a hypothesis of siluroid phylogeny. Theses Zoology 1991, 17:1-216.

86. Arratia G: Development and variation of the suspensorium of primitive catfishes (Teleostei: Ostariophysi) and their phylogenetic relationships. Bonn Zool Monogr 1992, 32:1-148.

87. De Pinna MCC: Phylogenetic relationships of Neotropical Siluriformes: History, overview and synthesis of hypotheses. In Phylogeny and Classification of Neotropical Fishes. Edited by: Malabarba LR, Reis RE, Vari RP, Lucena ZM, Lucena CAS. Porto Alegre, Brasil: Edipucrs; 1998:279-330.

88. He S, Gayet M, Meunier FJ: Phylogeny of the Amphiliidae (Teleostei: Siluriformes). Ann Sci Natur 1999, 20(4):117-146.

89. Diogo R, Peng Z: State of the art of siluriform higher-level phylogeny. In Gonorynchiformes and ostriophysan relationships: A comprehensive review. Edited by: Grande T, Poyato-Ariza FJ, Diogo R. Enfield, New Hampshire: Science Publishers; 2010:465-515.

90. Inoue JG, Miya M, Venkatesh B, Nishida M: The mitochondrial genome of Indonesian coelacanth Latimeria menadoensis (Sarcopterygii: Coelacanthiformes) and divergence time estimation between the two coelacanths. Gene 2005, 349:227-235.

91. Yamanoue $Y$, Miya M, Inoue JG, Matsuura K, Nishida M: The mitochondrial genome of spotted green pufferfish Tetraodon nigroviridis (Teleostei: Tetraodontiformes) and divergence time estimation among model organisms in fishes. Genes Genet Syst 2006, 81(1):29-39.

92. Inoue JG, Kumazawa Y, Miya M, Nishida M: The historical biogeography of the freshwater knifefishes using mitogenomic approaches: a Mesozoic origin of the Asian notopterids (Actinopterygii: Osteoglossomorpha). Mol Phylogenet Evol 2009, 51(3):486-499.

93. Arratia G: Basal teleosts and teleostean phylogeny. Palaeo-IChthyology 1997, 7:5-168.

94. Filleul A, Maisey JG: Redescription of Santanichthys diasii (Otophysi, Characiformes) from the Albian of the Santana Formation and comments on its implications for otophysan relationships. Am Mus Novit 2004, 3455:1-21.

95. Kumazawa $Y$, Azuma $Y$, Nishida M: Tempo of mitochondrial gene evolution: Can mitochondrial DNA be used to date old divergences? Endocytobiosis Cell Research 2004, 15:136-142.

96. Santini F, Harmon LJ, Carnevale G, Alfaro ME: Did genome duplication drive the origin of teleosts? A comparative study of diversification in ray-finned fishes. BMC Evol Biol 2009, 9(1):194.

97. Donoghue PCJ, Benton MJ: Rocks and clocks: calibrating the Tree of Life using fossils and molecules. Trends Ecol Evol 2007, 22(8):424-431.
98. Reisz RR, Müller J: Molecular timescales and the fossil record: a paleontological perspective. Trends Genet 2004, 20:237-241.

99. Müller J, Reisz RR: Four well-constrained calibration points from the vertebrate fossil record for molecular clock estimates. Bioessays 2005, 27: 1069-1075.

100. Hurley I, Mueller R, Dunn K, Schmidt E, Friedman M, Ho R, Prince V, Yang Z, Thomas M, Coates M: A new time-scale for ray-finned fish evolution. Proc R SOC B 2007, 274(1609):489-498.

101. Phillips MJ: Branch-length estimation bias misleads molecular dating for a vertebrate mitochondrial phylogeny. Gene 2009, 441(1-2):132-140.

102. Miya M, Saitoh K, Wood R, Nishida M, Mayden RL: New primers for amplifying and sequencing the mitochondrial ND4/ND5 gene region of the Cypriniformes (Actinopterygii: Ostariophysi). Ichthyol Res 2006, 53(1):75-81.

103. Buckup PA: The Characidiinae: a phylogenetic study of the South American darters and their relationships with other characiform fishes. Ph.D. thesis Ann Harbor: The University of Michigan; 1991

104. Storey BC: The role of mantle plumes in continental breakup: case histories from Gondwanaland. Nature 1995, 377:301-308.

105. Taverne $L$ : Les poissons crétacés de Nardò. $16^{\circ}$ Sorbinicharax verraesi gen. sp. nov. (Teleostei, Ostariophysi, Otophysi, Characiformes). Bollettino del Museo Civico di Storia Naturale di Verona 2003, 27:29-45.

106. Otero O, Valentin X, Garcia G: Cretaceous characiform fishes (Teleostei: Ostariophysi) from Northern Tethys: description of new material from the Maastrichtian of Provence (Southern France) and palaeobiogeographic implications. In Fishes and the break-up of Pangaea. Volume 295. Edited by: Cavin L, Longbottom A, Richter M. London: Geological Society, London, Special Publications; 2008:155-164.

107. Lundberg JG, Sullivan JP, Rodiles-Hernández R, Hendrickson DA: Discovery of African roots for the Mesoamerican Chiapas catfish, Lacantunia enigmatica, requires an ancient intercontinental passage. Proc Acad Nat Sci Phila 2007, 156(1):39-53.

108. Sanderson MJ: r8s ver. 1.70. 2004

109. Quental TB, Marshall CR: Diversity dynamics: molecular phylogenies need the fossil record. Trends Ecol Evol 2010, 25(8):434-441.

110. Benton MJ: Vertebrate palaeontology. Malden, MA: Blackwell; 32005.

111. Benton MJ, Tverdokhlebov VP, Surkov MV: Ecosystem remodeling among vertebrates at the Permian-Triassic boundary in Russia. Nature 2004, 432(7013):97-100.

112. Isozaki Y: Permo-Triassic boundary superanoxia and stratified superocean: records from lost deep sea. Science 1997, 276(5310):235-238.

113. Sperling EA, Ingle JC Jr: A Permian-Triassic boundary section at Quinn River Crossing, northwestern Nevada, and implications for the cause of the Early Triassic chert gap on the western Pangean margin. Bull Geol Soc Am 2006, 118(5-6):733-746

114. Grice K, Cao C, Love GD, B ttcher ME, Twitchett RJ, Grosjean E, Summons RE, Turgeon SC, Dunning W, Jin Y: Photic zone euxinia during the Permian-Triassic superanoxic event. Science 2005, 307(5710):706-709,

115. Jin $Y G$, Wang $Y$, Wang W, Shang $Q H$, Cao $C Q$, Erwin DH: Pattern of marine mass extinction near the Permian-Triassic boundary in South China. Science 2000, 289(5478):432-436.

116. Chapelle G, Peck LS: Polar gigantism dictated by oxygen availability. Nature 1999, 399(6732):114-115.

117. Huynh $\mathrm{TT}$, Poulsen $\mathrm{CJ}$ : Rising atmospheric $\mathrm{CO}_{2}$ as a possible trigger for the end-Triassic mass extinction. Palaeogeogr, Palaeoclimatol, Palaeoecol 2005, 217(3-4):223-242.

118. Dixon D, Jenkins I, Moody RTJ, Zhuravlev AY: Atlas of the evolving earth. Volume 2. From the Devonian to the Cretaceous. New York: Macmillan Reference USA; 2001

119. Guex J, Bartolini A, Atudorei V, Taylor D: High-resolution ammonite and carbon isotope stratigraphy across the Triassic-Jurassic boundary at New York Canyon (Nevada). Earth Planet Sci Lett 2004, 225(1-2):29-41.

120. Cooper A, Penny D: Mass survival of birds across the Cretaceous-Tertiary boundary: molecular evidence. Science 1997, 275:1109-1113.

121. López-Arbarello A: The record of Mesozoic fishes from Gondwana (excluding India and Madagascar). In Mesozoic fishes 3. Edited by: Arratia G, Tintori A. München, Germany: Verlag Dr. Friedrich Pfeil; 2004:597-624.

122. Wilson MVH, Bruner JC, Arratia G, Tintori A: Mesozoic fish assemblages of North America. Mesozoic fishes 3 München, Germany: Verlag Dr. Friedrich Pfeil: 2004, 575-595. 
123. Chang MM, Miao D, Arratia G, Tintori A: An overview of Mesozoic fishes in Asia. In Mesozoic fishes 3. Edited by: Arratia G, Tintori A. München, Germany: Verlag Dr. Friedrich Pfeil; 2004:535-563.

124. Milner ARC, Kirkland J, Birthisel TA: The geographic distribution and biostratigraphy of Late Triassic-Early Jurassic freshwater fish faunas of the southwestern United States. New Mexico Museum of Natural History and Science Bulletin 2006, 37:522-529.

125. Arratia G, Scasso R, Kiessling W: Late Jurassic fishes from Longing Gap, Antarctic Peninsula. J Vert Paleontol 2004, 24(1):41-55.

126. Smith AG, Smith DG, Funnell BM: Atlas of Mesozoic and Cenozoic coastlines. Cambridge, UK: Cambridge University Press; 2004.

127. Ziegler A, Eshel G, Rees PMA, Rothfus T, Rowley D, Sunderlin D: Tracing the tropics across land and sea: Permian to present. Lethaia 2003, 36(3):227-254

128. Janvier P: Early vertebrates. Oxford, UK: Oxford University Press; 1996.

129. Zhu M, Yu X, Wang W, Zhao W, Jia L: A primitive fish provides key characters bearing on deep osteichthyan phylogeny. Nature 2006, 441(7089):77-80

130. Patterson C: Osteichthyes: Teleostei. In The fossil record 2. Edited by: Benton MJ. London, UK: Chapman 1993:621-656.

131. Gayet $M$, Meunier FJ: Premiére découverte de Gymnotiformes fossiles (Pisces, Ostariophysi) dans le Miocène supérieur de Bolivie. CR Acad SC Paris 1991, 313(4):471-476.

132. Gayet M, Meunier FJ: Paleontology and palaeobiogeography of catfishes. In Catfishes. Edited by: Arratia G, Kapoor BG, Chardon M, Diogo R. Enfield, NH: Science Publishers; 2003:491-522.

133. Wilson MVH, Brinkman DB, Neuman AG: Cretaceous Esocoidei (Teleostei) early radiation of the pikes in North American fresh waters. J Paleontol 1992, 66:839-846.

134. Tyler JC, Sorbini L: New superfamily and three new families of tetraodontiform fishes from the Upper Cretaceous: the earliest and most morphologically primitive plectognaths. Smith Contr Paleobio 1996, 82:1-59.

135. Benton MJ, Donoghue PCJ, Asher RJ: Calibrating and constraining molecular clocks. In Timetree of life. Edited by: Hedges SB, Kumar S. Oxford, UK: Oxford University Press; 2009:35-86.

doi:10.1186/1471-2148-11-177

Cite this article as: Nakatani et al.: Evolutionary history of Otophysi

(Teleostei), a major clade of the modern freshwater fishes: Pangaean origin and Mesozoic radiation. BMC Evolutionary Biology 2011 11:177.

\section{Submit your next manuscript to BioMed Central and take full advantage of:}

- Convenient online submission

- Thorough peer review

- No space constraints or color figure charges

- Immediate publication on acceptance

- Inclusion in PubMed, CAS, Scopus and Google Scholar

- Research which is freely available for redistribution

Submit your manuscript at www.biomedcentral.com/submit 